\title{
Gene expression profiling of bovine peripartal placentomes: detection of molecular pathways potentially involved in the release of foetal membranes
}

\author{
Dominik Streyl, Rebecca Kenngott ${ }^{1}$, Nadja Herbach², Rüdiger Wanke², Helmut Blum³, \\ Fred Sinowatz ${ }^{1}$, Eckhard Wolf ${ }^{3,4}$, Holm Zerbe and Stefan Bauersachs ${ }^{3,}$
}

Clinic for Ruminants with Ambulatory and Herd Health Services, Centre for Clinical Veterinary Medicine, LMU Munich, 85764 Oberschleißheim, Germany, ${ }^{1}$ Department of Veterinary Sciences, Institute for Veterinary Anatomy, Histology and Embryology, LMU Munich, 80539 Munich, Germany, ${ }^{2}$ Institute of Veterinary Pathology, Centre for Clinical Veterinary Medicine, LMU Munich, 80359 Munich, Germany, ${ }^{3}$ Laboratory for Functional Genome Analysis (LAFUGA), LMU Munich, 81377 Munich, Germany and ${ }^{4}$ Chair for Molecular Animal Breeding and Biotechnology, Gene Center, LMU Munich, Germany

Correspondence should be addressed to D Streyl; Email: d.streyl@Imu.de

$\mathrm{H}$ Zerbe and S Bauersachs contributed equally to this work

\begin{abstract}
The mechanisms underlying detachment of foetal membranes after birth in cows are still unclear. To address this problem in a systematic manner, we performed the first holistic transcriptome study of bovine placentomes antepartum (AP; $n=4$ cows) and intrapartum (IP; $n=4$ cows) using Affymetrix GeneChip Bovine Genome Arrays. Three placentomes were extracted from each cow, and tissue samples from the contact zones of the placentomes (foeto-maternal units) were recovered by systematic random sampling and processed for RNA extraction and for stereological quantification of cellular composition. Statistical analysis of microarray data (false discovery rate $1 \%$ ) revealed 759 mRNAs with at least twofold higher levels in the samples of the AP group, whereas 514 mRNAs showed higher levels in the IP group. The differentially expressed genes were classified according to biological processes and molecular functions using the Functional Annotation Clustering tool of the DAVID Bioinformatics Resources. Genes with higher mRNA levels in the AP group were nearly completely related to mitotic cell cycle and tissue differentiation. During parturition, a complete shift occurred because the genes with higher mRNA levels in IP were nearly all related to three different physiological processes/complexes: i) apoptosis, ii) degradation of extra cellular matrix and iii) innate immune response, which play a fundamental role in placental detachment. These results are an excellent basis for future studies investigating the molecular basis of retained foetal membranes.
\end{abstract}

Reproduction (2012) 143 85-105

\section{Introduction}

Anatomically, the bovine placenta is characterised as synepitheliochorial placenta (Wooding et al. 1997). It consists of 70-150 functional foeto-maternal units (Björkman \& Sollen 1960), the placentomes. Each placentome is composed of a maternal caruncle and a foetal cotyledon. With ongoing pregnancy, the foetal villi invade intimately and extensively within the deeper branching caruncular crypts (reviewed in McNaughton \& Murray (2009)).

Towards the end of pregnancy, placental maturation is a prerequisite for the subpartal detachment and release of foetal membranes. At the cellular level, the placental maturation is characterised by typical changes of the maternal crypt epithelium, which decreases in height and number of cells. Additionally, contacts with foetal trophoblastic cells increase as well with the underlying maternal connective tissue (Boos et al. 2003). Areas denuded of epithelial cells also appear within the maternal epithelial lining of the crypts. Placental maturation results in a reduction of the distance between the foetal and maternal blood supplies to meet the growing nutritional demands of the foetus in the last months of pregnancy (Björkman 1954, Björkman \& Sollen 1960, Woicke et al. 1986, Williams et al. 1987, Schoon 1989, Stallmach et al. 2001).

The initiation of parturition occurs as a result of activation of the foetal hypothalamus-pituitary-adrenal (HPA) axis. The reasons for its activation are still not elucidated, but different theories are discussed: maturation of the foetal hypothalamus; response of the foetal hypothalamus to placental hormones; and foetal 
stressors due to hypoxia, hypocapnia, changes in blood pressure or blood glucose (reviewed in Wood (1999)). By activation of the HPA, the ACTH is released by the pituitary. In parallel, the binding capacity of the plasma for cortisol increases, which reduces the free cortisol and this reduces the negative feedback effect of ACTH to the pituitary. Additionally, the response of the foetal adrenal glands increases with foetal age (Glickman \& Challis 1980). The increase in foetal cortisol concentration induces the endometrial prostaglandin synthesis by two different pathways (Whittle et al. 2000): oestrogen dependent as well as oestrogen independent. In the oestrogen-independent pathway, cortisol enhances the expression of prostaglandin synthase (PTGS2) within the foetal trophoblast cells of the placenta. Therefore, prostaglandin $\mathrm{E}_{2}\left(\mathrm{PGE}_{2}\right)$ is released in the placenta, which stimulates the conversion of pregnenolone to C19 steroids, which are aromatised by $17 \alpha$-hydroxylase and aromatase to oestrogens. This increase in oestrogen levels leads to the activation of PTGS2 in the maternal endometrium, which increases the production and release of $\mathrm{PGF}_{2 \alpha}$. The effects of $\mathrm{PGF}_{2 \alpha}$ are different. In the myometrium, it lowers the threshold of the oxytocin receptor to respond to oxytocin and increases by this the myometrial contractions indirectly, but has also a direct effect on the myometrium (reviewed by Taverne \& Noakes (2009)). Another effect of the increased $\mathrm{PGF}_{2 \alpha}$ production, which has been shown in cows and goats, is the induction of regression of the corpus luteum. Therefore, prostaglandins are main regulators of the initiation of parturition and are essential for initiating smooth muscle contractions.

Oestrogen has also a direct effect on the myometrium by increasing contraction-associated proteins (Olson 2003, Mendelson 2009), like connexins, which form gap junctions to coordinate myometrial contractions. Another essential effect of oestrogens is the softening of the birth canal, namely the cervix, the vagina and the associated tissues, by altering the structure of collagen fibres (reviewed by Taverne \& Noakes (2009)).

The separation of the placental components involves a wide range of different processes. An increase in the proportion of collagen in the cotyledons throughout gestation in contrast to a decreased proportion in the maternal part was demonstrated (Sharpe et al. 1989). During labour, contractions of the myometrium result in pressure changes in the cotyledonary villi leading to alternating hyperaemic and ischaemic conditions and finally the physical separation of the foeto-maternal unit (reviewed in McNaughton \& Murray (2009)). Furthermore, the cotyledonary villi collapse when the umbilical cord ruptures in parturition (Joosten \& Hensen 1992), resulting in a reduced surface area. At the cellular level, this process is characterised by a number of morphological changes in the maternal crypt epithelium. Shortly before parturition, the number of epithelial cells increases in contrast to the number of giant trophoblast cells (GC) that is reduced (Boos et al. 2003). It has also been described that the expression of major histocompatibility complex class II (MHC-II) in a subset of binucleate cells (BNC) in the near term placentomes is beneficial for the maturation process. These MHC-II antigens of the foetus are presented to the dam, which modulates the maternal immune system required for the placental separation (reviewed in McNaughton \& Murray (2009)). The roles of single extracellular matrix-degrading enzymes, namely matrix metallopeptidases 2 (MMP2) and 9 (MMP9), as well as of the tissue inhibitor of metallopeptidase 2 (TIMP2) in placental maturation have been studied during parturition. It has been shown by immunohistological analysis as well as gene expression analysis that these genes are associated with the process of expulsion of the foetal membranes (Walter \& Boos 2001, Boos et al. 2003, Takagi et al. 2007). Further, an increase in the number of apoptotic cells in maternal crypt epithelium, maternal stroma and foetal chorionic epithelium during pregnancy has been observed, suggesting an important role of regulated cell death in normal expulsion of the foetal membranes (Boos et al. 2003).

Retained foetal membranes (RFM) in cattle is defined as the failure to expel foetal membranes within a physiological time period of 8-12 h post partum (Sheldon 2004). RFM can lead to life threatening conditions in mammals including women. For dairy cows, there is an average incidence of 3-12\% in industrialised countries (Esslemont \& Kossaibati 1996, Sheldon 2004) also demonstrating the economic importance of this complication.

So far, many studies of single genes at the mRNA or protein level were performed that analysed only single aspects of this complex process. To obtain a more holistic view, a transcriptome analysis of well-defined tissue samples before and intraparturition was performed to identify changes in mRNA concentrations that indicate molecular pathways involved in the regulation of detachment of the foetal membranes. This improved understanding can help to facilitate the development of new strategies in the prevention and therapy of RFM.

\section{Results \\ Morphometrical analysis}

To ensure the comparability of the tissue samples with regard to cellular composition, the volume fraction of the epithelial cells of each sample was determined by morphometrical analysis. Whereas the variation in the volume fraction of epithelial cells between individual tissue samples was relatively high ( $V_{v} \quad 0.02-0.47$ epithelial cells), the variation between animals (mean volume fraction of epithelial cells of all nine tissue samples per animal $V_{v}$ 0.15-0.35) was clearly reduced due to the pooling of samples per animal. There was no significant difference between the experimental groups (P>0.5; Fig. 1). 
A

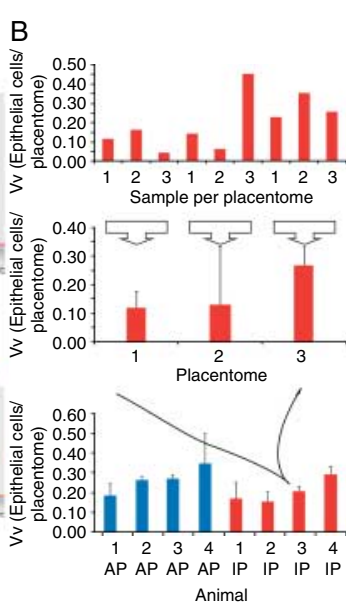

Figure 1 (A) Scheme of systematic random sampling. Cross sections of a placentome covered by a grid $(1 \times 1 \mathrm{~cm})$ are shown; grey: epithelial tissue of the caruncle; light grey: caruncle stroma; red: epithelial tissue of the cotyledon. Ovals indicate the crosses of the grid lying on the zone of foeto-maternal contact. Filled ovals indicate the locations of tissue sampling (adapted, with permission, from Fig. 8.9 in Rüsse I \& Sinowatz $\mathbf{F}$

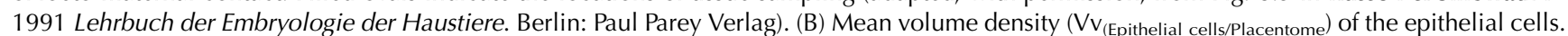
The S.D. is marked by a bar. In the upper diagram, three placentomes of one animal (three IP) were shown. Three placentomes were sampled per animal. In the middle diagram, the mean volume density of each placentome per animal was shown. In the lowest diagram, the mean volume density of epithelial cells is shown for all the eight animals.

\section{Microarray analysis}

To identify peripartal transcriptome changes in the foetomaternal unit, samples recovered 12 days before the estimated day of calving (antepartum (AP), $n=4$ ) and samples taken immediately after delivery of the calf (intrapartum (IP), $n=4$ ) were analysed using Affymetrix GenChip Bovine Genome Arrays. In total, eight Affymetrix microarrays were hybridised and evaluated. A heatmap of the pair-wise distances of the single data sets showed high correlation between the animals of the individual experimental groups (data not shown). Statistical analysis (SAM, two-class unpaired (Tusher et al. 2001)) revealed 1650 probe sets with significant differences (false discovery rate $1 \%, \geq$ twofold) in their hybridisation signals between the placentomes of the AP group vs the IP group. These probe sets corresponded to 1226 different genes, 743 with higher transcript levels AP and 483 with higher levels IP (Supplementary Table 2, see section on supplementary data given at the end of this article). Twelve selected genes were verified by quantitative real-time RT-PCR (Table 1). The corresponding primer sets are shown in Supplementary Table 1, see section on supplementary data given at the end of this article.

The differentially expressed genes were analysed with the Functional Annotation Clustering tool of the Database for Annotation, Visualization and Integrated Discovery (DAVID) Bioinformatics Resources. The result of this integrated analysis of different functional databases (e.g. GO, KEGG pathways, SP-PIR keywords, etc.) are clusters of quantitatively enriched functional terms with overlapping sets of genes with a significant cluster enrichment score (geometric mean in log scale

Table 1 Results of quantitative real-time RT-PCR.

\begin{tabular}{|c|c|c|c|c|c|c|c|c|}
\hline \multirow[b]{2}{*}{ Gene } & \multicolumn{2}{|c|}{ Mean $C_{\mathrm{T}}$} & \multicolumn{2}{|c|}{ S.D. } & \multicolumn{2}{|c|}{ qPCR } & \multicolumn{2}{|c|}{ Array } \\
\hline & IP & AP & IP & AP & FC IP/AP & $P$ value & FC IP/AP & $P$ value \\
\hline$B 2 M$ & 19.1 & 19.9 & 0.4 & 0.7 & 1.9 & 0.037 & 1.3 & 0.004 \\
\hline$C D 14^{\mathrm{a}}$ & 28.5 & 30.7 & 0.8 & 1.6 & 5.8 & 0.014 & 2.8 & $<0.001$ \\
\hline CXCL2 & 25.5 & 27.8 & 0.5 & 0.7 & 4.4 & 0.001 & 4.5 & $<0.001$ \\
\hline FGF2 & 31.6 & 33.6 & 1.0 & 0.8 & 3.3 & 0.021 & 2.3 & $<0.001$ \\
\hline$G P X 3$ & 22.1 & 23.3 & 0.5 & 0.7 & 2.6 & 0.002 & 2.4 & $<0.001$ \\
\hline$H P G D^{a}$ & 26.3 & 27.3 & 1.2 & 0.5 & 2.4 & 0.051 & 2.4 & 0.005 \\
\hline MT2A & 23.9 & 25.7 & 1.0 & 0.6 & 3.8 & 0.005 & 2.4 & $<0.001$ \\
\hline PTX 3 & 31.9 & 34.0 & 0.6 & 1.2 & 3.4 & 0.021 & 2.7 & $<0.001$ \\
\hline$S D S^{\mathrm{a}}$ & 27.4 & 28.9 & 0.9 & 0.5 & 3.5 & 0.010 & 3.1 & $<0.001$ \\
\hline KLF5 & 26.3 & 25.0 & 0.6 & 0.8 & -2.9 & 0.014 & -2.1 & $<0.001$ \\
\hline$\angle B P$ & 34.6 & 33.0 & 1.1 & 0.9 & -3.7 & 0.036 & -2.1 & $<0.001$ \\
\hline TRIB3 & 24.3 & 21.4 & 0.8 & 0.4 & -8.6 & 0.001 & -5.1 & $<0.001$ \\
\hline
\end{tabular}

FC, fold change.

${ }^{\text {a }}$ Roche master mix, all others with $\mathrm{ABI}$ master mix. 
Table 2 Results of functional annotation clustering of genes up-regulated 12 days antepartum.

\begin{tabular}{|c|c|c|}
\hline Functional annotation cluster description ${ }^{a}$ & $\begin{array}{l}\text { Enrichm. } \\
\text { score }^{b}\end{array}$ & Genes $^{c}$ \\
\hline $\begin{array}{l}\text { Cell cycle }(63,4.2) \text {, mitotic cell cycle }(54,4.6) \text {, cell division }(45,6.2), \mathrm{M} \text { phase of mitotic cell cycle }(45,5.3) \text {, } \\
\text { mitosis }(38,8.2)\end{array}$ & 19.15 & 91 \\
\hline Cell cycle $(63,4.2)$, regulation of cell cycle $(41,2.1)$ & 12.72 & 90 \\
\hline Chromosome $(35,2.4)$, chromosome pericentric region $(19,6.9)$, centromere $(14,11.4)$ & 6.65 & 35 \\
\hline $\begin{array}{l}\text { Chromosome organisation and biogenesis }(24,1.7) \text {, chromosome segregation }(14,6.0) \text {, mitotic sister chromatic } \\
\text { segregation }(10,8.8)\end{array}$ & 4.98 & 25 \\
\hline Microtubule cytoskeleton $(37,2.4)$, cytoskeleton $(71,1.6)$, intracellular non-membrane-bound organelle $(107,1.4)$ & 4.48 & 107 \\
\hline $\begin{array}{l}\text { Cytoskeleton organisation and biogenesis }(39,2.0) \text {, microtubule cytoskeleton organisation and biogenesis }(12,3.9) \text {, } \\
\text { spindle organisation and biogenesis }(7,9.5)\end{array}$ & 3.75 & 37 \\
\hline $\begin{array}{l}\text { Substrate-specific transmembrane transporter }(43,1.3) \text {, symporter activity }(19,3.3) \text {, solute: sodium symporter } \\
\text { activity }(11,6.0) \text {, carboxylic acid transmembrane activity }(9,3.4) \text {, organic acid: sodium symporter activity }(7,7.9)\end{array}$ & 2.88 & 46 \\
\hline $\begin{array}{l}\text { Enzyme regulator activity }(48,1.6) \text {, regulation of signal transduction }(38,1.8), \text { GTPase regulator activity }(29,2.0) \text {, } \\
\text { small GTPase regulator activity }(22,2.4) \text {, Ras protein signal transduction }(20,2.1) \text {, Rho protein signal } \\
\text { transduction }(12,2.8) \text {, Ras guanyl nucleotide exchange factor activity }(11,3.4) \text {, Rho guanyl-nucleotide exchange } \\
\text { factor activity }(10,3.6)\end{array}$ & 2.40 & 82 \\
\hline $\begin{array}{l}\text { Cytoskeletal part }(49,1.8) \text {, microtubule }(20,2.3) \text {, microtubule-based process }(19,2.3) \text {, cytoskeleton-dependent } \\
\text { intracellular transport }(10,2.1)\end{array}$ & 2.01 & 54 \\
\hline $\begin{array}{l}\text { Purine nucleotide binding }(89,1.3) \text {, nucleotide binding }(75,1.4) \text {, ATP-binding }(63,1.5) \text {, nucleotide phosphatase- } \\
\text { binding region: ATP }(53,1.8) \text {, kinase activity }(53,1.5) \text {, protein amino acid phosphorylation }(36,1.4)\end{array}$ & 1.97 & 190 \\
\hline $\begin{array}{l}\text { Cellular lipid metabolic process }(33,1.4) \text {, steroid metabolic process }(15,2.2) \text {, lipid synthesis }(9,2.9) \text {, steroid } \\
\text { biosynthesis }(7,5.4)\end{array}$ & 1.87 & 39 \\
\hline $\begin{array}{l}\text { Development process }(152,1.3) \text {, cell differentiation }(87,1.3) \text {, cell development }(65,1.4) \text {, apoptosis }(43,1.5), \\
\text { programmed cell death }(43,1.5) \text {, regulation of apoptosis }(27,1.4) \text {, negative regulation of apoptosis }(17,2.0)\end{array}$ & 1.83 & 152 \\
\hline Endosome $(18,2.4)$; endosome membrane $(8,2.4)$ & 1.81 & 18 \\
\hline Oxidoreductase $(33,1.6)$, iron ion binding $(18,1.6)$ & 1.58 & 45 \\
\hline Calmodulin binding $(10,2.1)$, IQ calmodulin-binding region $(8,2.7)$ & 1.39 & 11 \\
\hline Cytoskeleton protein binding $(26,1.7)$, actin cytoskeleton $(18,1.8)$, actin binding $(16,1.5)$ & 1.35 & 33 \\
\hline
\end{tabular}

${ }^{a}$ Based on the most meaningful terms. ${ }^{b}$ Geometric mean (in $-\log _{10}$ scale) of member's $P$ values of the corresponding annotation cluster. ${ }^{\mathrm{c}}$ Total number of different genes in a functional annotation cluster; in brackets: number of genes and fold enrichment of the functional term.

of member's Fisher Exact $P$ values in a corresponding annotation cluster). Before parturition, most significant clusters were related to cell cycle and cell division, transmembrane transporters and regulation of signal transduction (Table 1). In parturition, the highest enrichment scores were obtained for clusters related to immune response, extracellular proteins, regulation of apoptosis and different categories involved in tissue remodelling (Table 2). The results of the text mining of Medline abstracts (CoPub analysis) overall confirmed the results of the DAVID analysis. For the genes with higher mRNA levels in the AP placentome samples, almost all overrepresented keywords were related to cell cycle (46 genes) and the different phases of mitosis, including DNA replication (24 genes) and its regulation (six genes; Supplementary Table 3, see section on supplementary data given at the end of this article). The analysis of the IP up-regulated genes showed overrepresented keywords related to innate immune response (20 genes), membrane degradation (11 genes), inhibition of matrix metallopeptidases (MMPs; five genes) and angiogenesis (13 genes; Supplementary Table 4, see section on supplementary data given at the end of this article).

Using Pathway Architect software, interaction networks were built for genes up-regulated during parturition. DAVID clusters with similar functional terms were further integrated resulting in three large functional groups: immune response (clusters 1, 2, 5, 10,
$11,14,22,25)$, combination of different clusters related to tissue remodelling (clusters $4,6,8,9,13,17,27$ ) and apoptosis (cluster 7). Each of these functional groups was analysed by CoPub and the overrepresented genes were used in the interaction networks. Networks were drawn based on different types of interactions like binding, regulation, expression, transport, assignment to a protein family or a biological process. Proteins were assigned to their primary cellular localisation. Figure 2 shows the interaction network for the genes involved in immune response (31 genes assigned). The network of genes involved in apoptosis (15 genes assigned) is shown in Fig. 3. Figure 4 shows the network of genes related to tissue remodelling (37 genes assigned; Tables 3-6).

\section{Localisation of selected proteins}

To examine the expression pattern and the localisation of PTGS2, MMP14, TIMP1 nuclear factor of kappa light polypeptide gene enhancer in B-cells inhibitor, alpha (NFKBIA), BCL2/adenovirus E1B 19 kDa interacting protein 3 (BNIP3) and X-linked inhibitor of apoptosis (XIAP), we have carried out immunohistochemical investigations using paraffin sections from formalinfixed bovine placentomes, which were taken AP or during birth (IP; Fig. 5 and Table 7).

Staining intensity for the antibody against PTGS2 (alias COX2) was moderate to distinct positive in the 


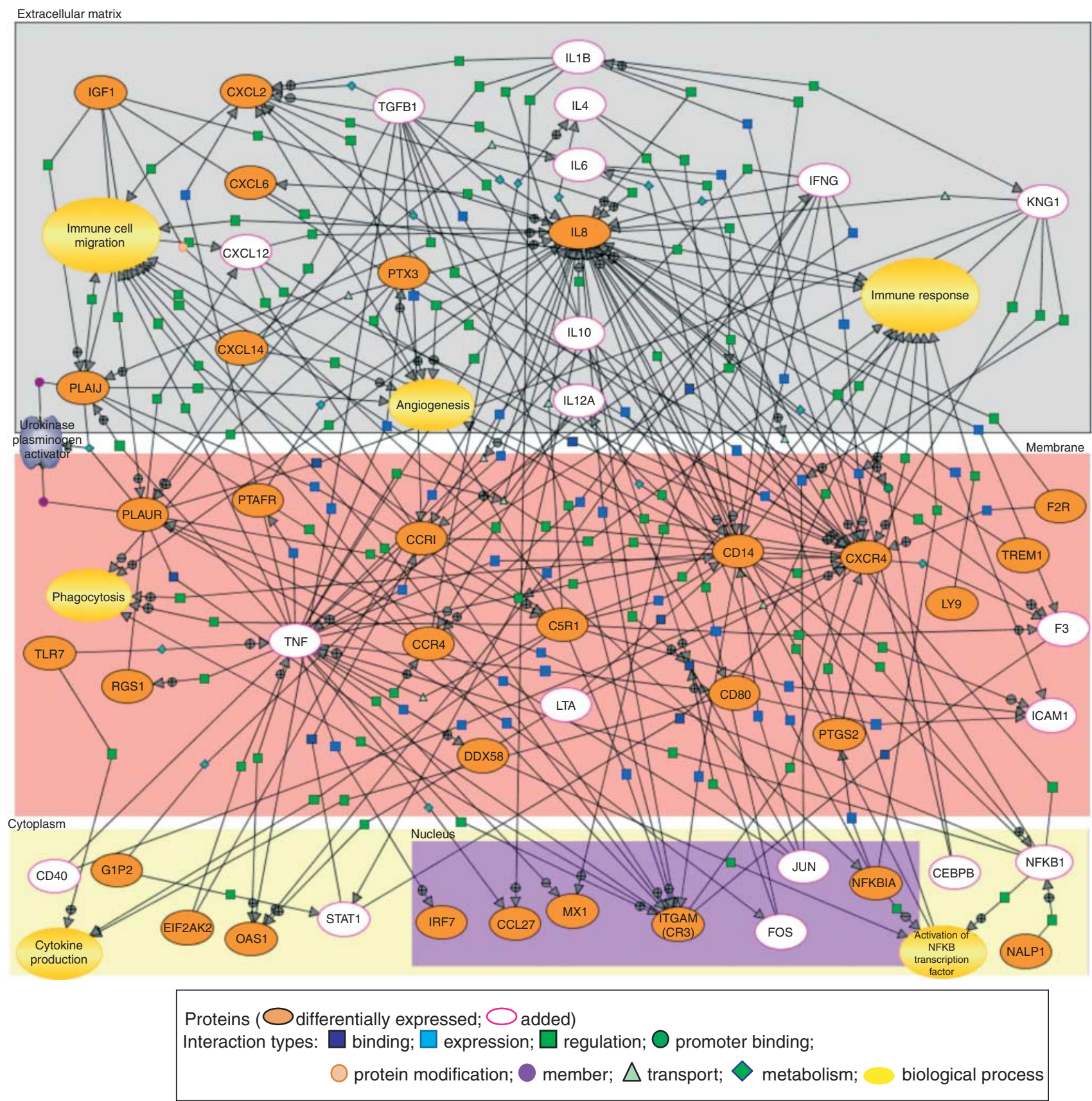

Figure 2 Interaction network of genes with higher mRNA levels in intrapartum related to immune response processes. Proteins (orange if differentially expressed and white with a pink outline if added) are assigned to their primary cellular localisations. Interaction types: dark blue squares: binding; light blue squares: expression; green squares: regulation; green circles: promoter binding; orange circles: protein modification; purple circles: member; green triangle: transport; cyan diamond: metabolism; yellow ovals: biological process.

uninucleated trophoblast cells (UNC) during the AP period, whereas in samples from IP placentomes the cytoplasmic expression of PTGS2 was increased and could be estimated as strong. No distinct immunostaining for PTGS2 could be observed in GC at both time points. The caruncular epithelial cells covering the basal plate and the septa displayed a weak to moderate cytoplasmic expression for PTGS2. No PTGS2 staining was found in stromal cells of the uterus AP and IP. IP, a few PTGS2-positive mesenchymal cells, could be detected in the foetal stroma.

In IP samples, MMP14 was mostly expressed in the UNC and GC. The immunostaining varied from distinct to strongly positive. In the epithelium and the stroma of the caruncular epithelium, a weak to moderate immunostaining for MMP14 could be detected. The mesenchymal cells of the chorionic plate and the primary villi showed a weak positive reaction with the antibody 

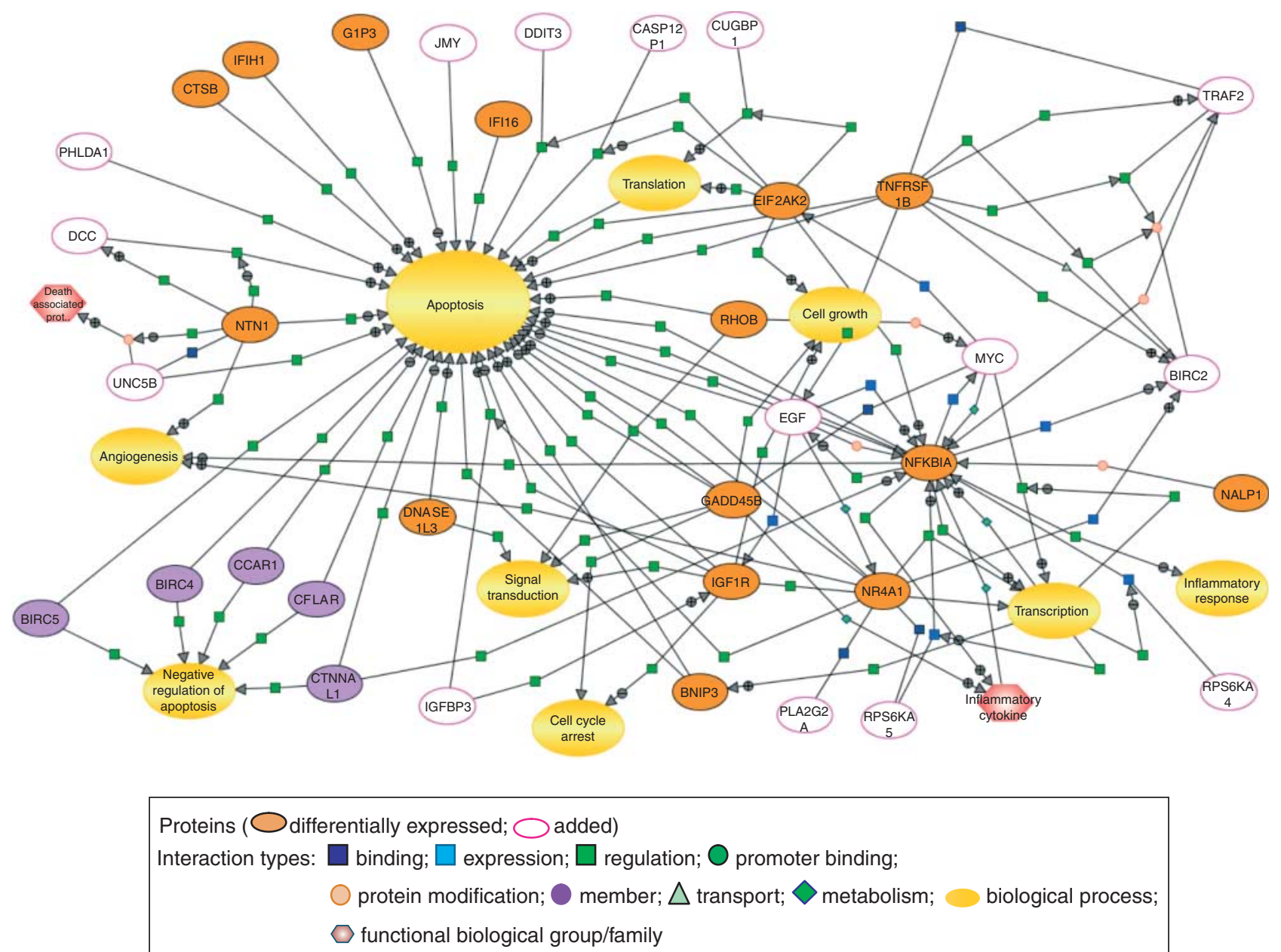

Figure 3 Interaction network of genes with highest mRNA levels intrapartum according to DAVID clusters associated with cell death. Proteins (orange if differentially expressed and white with a pink line, if added) are assigned to their primary cellular localisations. Interaction types: dark blue squares: binding; light blue squares: expression; green squares: regulation; green circles: promoter binding; orange circles: protein modification; purple circles: member; green triangle: transport; cyan diamond: metabolism; yellow ovals: biological process; red hexagons: functional biological group/family.

against MMP14. In AP samples, no difference for the staining intensity for MMP14 in the caruncular epithelium was observed. UNC expressed MMP14 moderately, whereas the GC generally showed no or only weak expression of MMP14. The endotheliums of the foetal or maternal blood vessels were usually distinct positive for MMP14. The foetal stroma cells of all villi displayed a weak positive reaction for MMP14. In contrast, the maternal stromal cells were negative.

TIMP1 immunostaining in the UNC appeared weak to moderate positive in AP samples, whereas the GC expressed TIMP1 with a moderate to distinct intensity. In IP, the staining intensity increased and could be considered as distinct to strong positive in both cell types. In the foetal stroma, the staining intensity was stronger in AP. The caruncular epithelial cells showed a moderate staining in IP, but somewhat attenuated immunostaining for TIMP1 was seen in the specimen obtained from AP. The maternal stromal cells showed a negative to weak expression before birth, which further increased to moderate expression in the IP samples.

NFKBIA was localised in the UNC and GC in both AP and IP bovine placentomes, but the staining intensity of the UNC appeared more distinct in IP samples. The maternal and foetal stroma showed a weak or moderate staining at both time points. The expression in the caruncular epithelium was weak to distinct positive and no differences between the AP and IP samples could be detected. Interestingly, during the antepartal phase, the endothelium of the blood vessels was immunopositive for NFKBIA, but appeared negative during IP.

BNIP3 was expressed only weakly in some scattered UNC and GC in IP samples. No immunostaining was observed in UNC and GC in AP samples. Caruncular epithelium and foetal stroma showed no BNIP3 immunostaining at both stages, whereas the staining intensity appeared as increased in uterine stromal cells of samples taken during birth. 


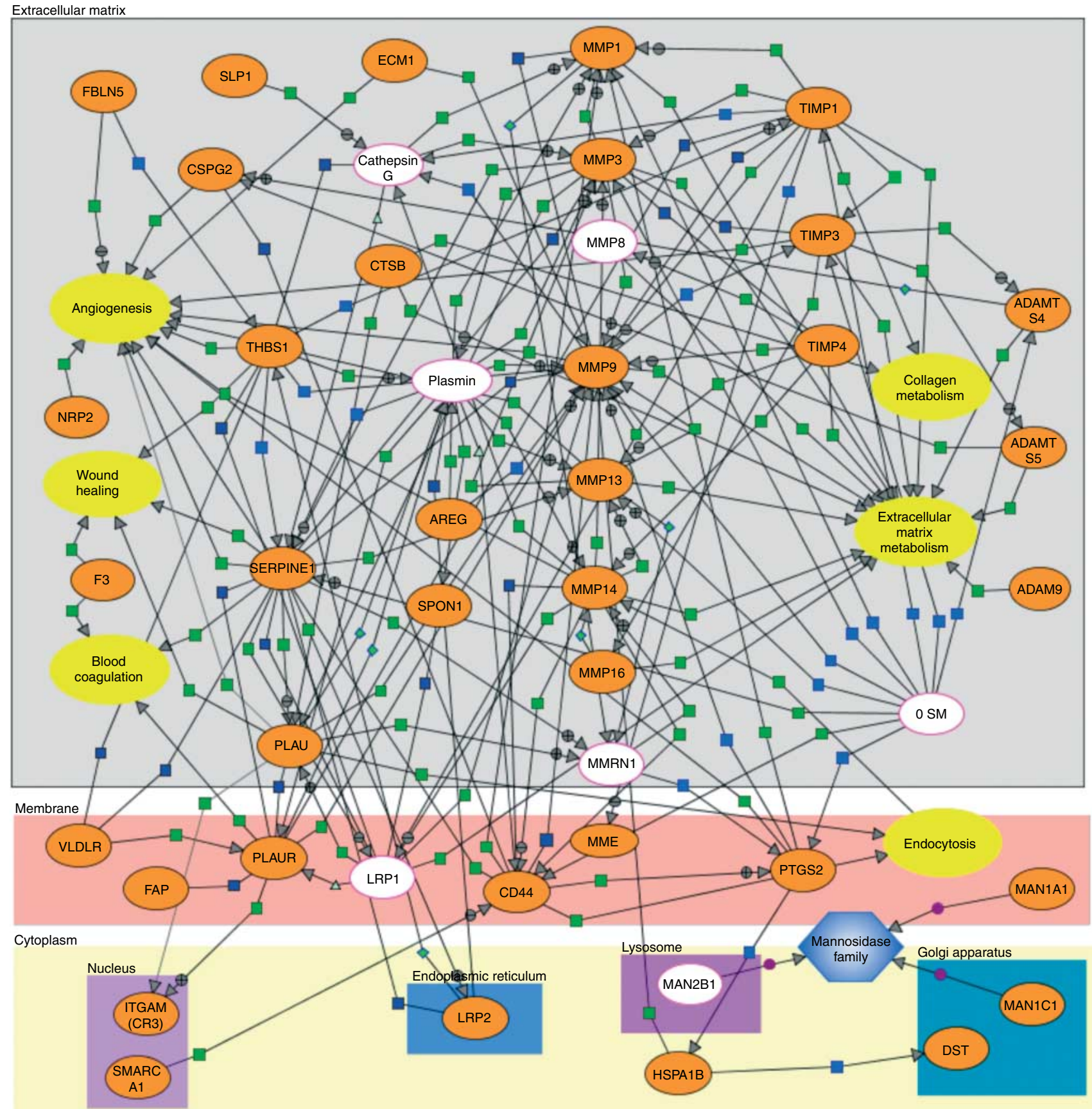

Proteins ( $\bigcirc$ differentially expressed; $\bigcirc$ added)

Interaction types: $\square$ binding; $\square$ expression; $\square$ regulation; $\bigcirc$ promoter binding;

$\bigcirc$ protein modification; member; $\triangle$ transport; $\triangle$ metabolism;

biological process; $\square$ functional biological group/family

Figure 4 Interaction network of genes with higher mRNA levels in intrapartum related to extracellular matrix remodelling. Proteins (orange if differentially expressed and white with a pink outline if added) are assigned to their primary cellular localisations. Interaction types: dark blue squares: binding; light blue squares: expression; light green squares: regulation; green circles: promoter binding; orange circles: protein modification; purple circles: member; green triangle: transport; cyan diamond: metabolism; yellow ovals: biological process; blue hexagons: functional biological group. 
Table 3 Results of functional annotation clustering of genes up-regulated intrapartum.

Response to stress $(64,2.2)$, response to external stimulus $(54,3.1)$, defence response $(43,2.7)$, response to

(40,3.4), response inflammatory $(28,3.4)$

Response to stimulus $(135,1.6)$, immune system process $(75,2.3)$, immune response

Membrane $(172,1.3)$, glycoprotein $(170,1.7)$, signal $(157,2.1)$, transmembrane $(144,1.3)$, signal peptide $(138,1.7)$, secreted $(91,2.5)$, extracellular region $(79,2.2)$

Extracellular region $(79,2.2)$, extracellular matrix $(28,3.0)$, proteinaceous extracellular matrix $(27,2.9)$

Multi-organism process $(28,3.2)$, response to biotic stimulus $(25,2.9)$, response to virus $(15,5.5)$

Development process $(134,1.5)$, cell differentiation $(85,1.7)$, cellular development process $(85,1.7)$, cell death $(47$,

$2.1)$, apoptosis $(44,2.0)$, regulation of programmed cell death $(31,2.1)$, positive regulation of apoptosis $(19,2.7)$

Organ morphogenesis $(25,2.2)$, vascular development $(18,3.4)$, anatomical structure formation $(17,3.3)$, angiogenesis $(16,4.1)$

Hydrolase activity $(88,1.4)$, protease $(29,2.4)$, zymogene $(18,3.6)$, metalloendopeptidase activity $(14,4.6)$

Response to chemical stimulus $(46,2.8)$, behaviour $(25,2.8)$, cytokine-cytokine receptor interaction $(19,1.7)$, chemotaxis $(17,4.2)$, G-protein-coupled receptor binding $(10,4.9)$, chemokine activity $(7,5.3)$

Carbohydrate binding $(22,2.6)$, pattern binding $(13,4.2)$, polysaccharide binding $(12,4.2)$, glycosaminoglycan binding $(11,4.0)$

Carboxylic acid metabolic process $(35,2.2)$, organic acid metabolic process $(35,2.2)$, cellular lipid metabolic process $(35,2.0)$, monocarboxylic acid metabolic process $(22,3.3)$, amine metabolic process $(21,1.7)$, fatty acid metabolic process $(17,3.5)$

Enzyme inhibitor activity $(17,2.3)$, endopeptidase inhibitor activity $(14,3.2)$, protease inhibitor activity $(14,3.2)$, serine-type endopeptidase inhibitor activity $(9,3.1)$

Regulation of development process $(16,2.2)$, hemopoietic or lymphoid development $(15,2.7)$, immune system development $(15,2.5)$, regulation of cell differentiation $(13,3.0)$, myeloid cell differentiation $(11,4.4)$

EGF-like region (22, 2.7), EGF-like, type 3 (16, 2.9), EGF-like calcium binding $(9,3.3)$, aspartic acid and asparagines hydroxylation site $(9,3.2)$

Regulation of body fluid levels $(12,3.6)$, wound healing $(10,2.8)$, blood coagulation $(9,3.3)$, haemostasis $(9,3.1)$

Membrane organisation and biogenesis $(18,2.2)$, membrane invagination $(15,2.8)$, endocytosis $(15,2.8)$

Cell communication $(144,1.3)$, signal transduction $(131,1.3)$, intracellular signalling cascade $(59,1.4)$, cell surface receptor-linked signal transduction $(59,1.1)$

Membrane fraction $(37,1.9)$, endoplasmic reticulum $(20,1.4)$, vesicular fraction $(13,2.7)$, microsome $(12,2.6)$

Immune effector process $(11,3.5)$, adaptive immune response $(8,3.6)$, lymphocyte-mediated immunity $(7,3.4)$

Reproduction $(21,1.4)$, reproductive process $(18,2.1)$, reproductive process in a multicellular organism $(8,4.0)$

Signal transducer activity $(87,1.3)$, receptor activity $(64,1.2)$, transmembrane protein $(39,2.4)$

Leukocyte activation $(13,2.3)$, lymphocyte activation $(12,2.4)$, T-cell activation $(8,2.5)$

Chemical homeostasis $(17,2.3)$, cellular ion homeostasis $(13,2.2)$, metal ion homeostasis $(9,2.5)$, cytosolic Ca ion homeostasis $(7,3.7)$

Cellular structure morphogenesis $(23,1.7)$, cell morphogenesis $(23,1.7)$, cell growth $(11,2.1)$, regulation of cell growth $(9,2.1)$

Regulation of molecular function $(25,1.6)$, regulation of catalytic activity $(23,1.7)$, regulation of protein kinase activity $(13,2.1)$, positive regulation of protein catalytic activity $(13,2.0)$

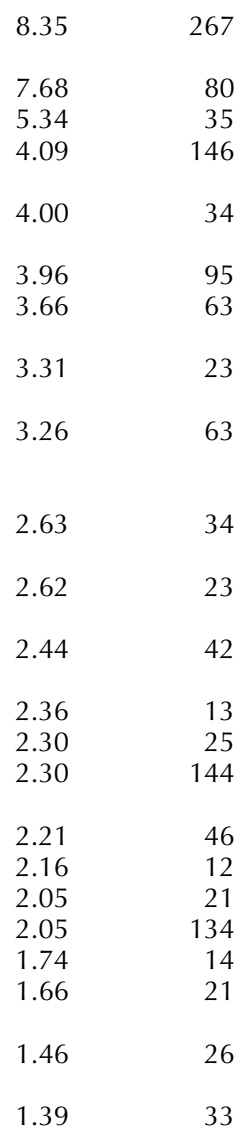

${ }^{\mathrm{a}}$ Based on the most meaningful terms. ${ }^{\mathrm{b}}$ Geometric mean (in $-\log _{10}$ scale) of member's $P$ values of the corresponding annotation cluster. ${ }^{\mathrm{c}}$ Total number of different genes in a functional annotation cluster; in brackets: number of genes and fold enrichment of the functional term.

UNC and GC displayed a distinct to strong immunostaining for XIAP in IP samples, which appeared weaker in AP samples. At both time points, the expression for XIAP was weak in the caruncular epithelium and moderate positive in foetal stromal cells. Maternal stromal cells were always negative for XIAP.

There were no staining reactions in all used negative controls (Supplementary Figure 1, see section on supplementary data given at the end of this article).

\section{Discussion}

The detailed molecular correlates of the process of release of foetal membranes and the early steps of uterine involution are unknown. Therefore, we performed the first holistic transcriptome analysis of foeto-maternal units recovered from a defined animal model AP and IP. This study facilitated a global detection of differential gene expression and the identification of potentially involved molecular pathways.

\section{Animal model and tissue sampling}

In this study, bovine placentome samples collected before the expected date of delivery (group AP) and samples taken from IP-extracted placentomes (group IP) were compared. Samples of group AP were collected 12-15 days before estimated term after undisturbed gestation with an active $\mathrm{Cl}\left(\mathrm{P}_{4}>2 \mathrm{ng} / \mathrm{ml}\right)$ because a decrease in $\mathrm{P}_{4}$ induces a significant shift in steroid secretion (Takagi et al. 2002) and decreases epithelial proliferation significantly. The AP samples were 


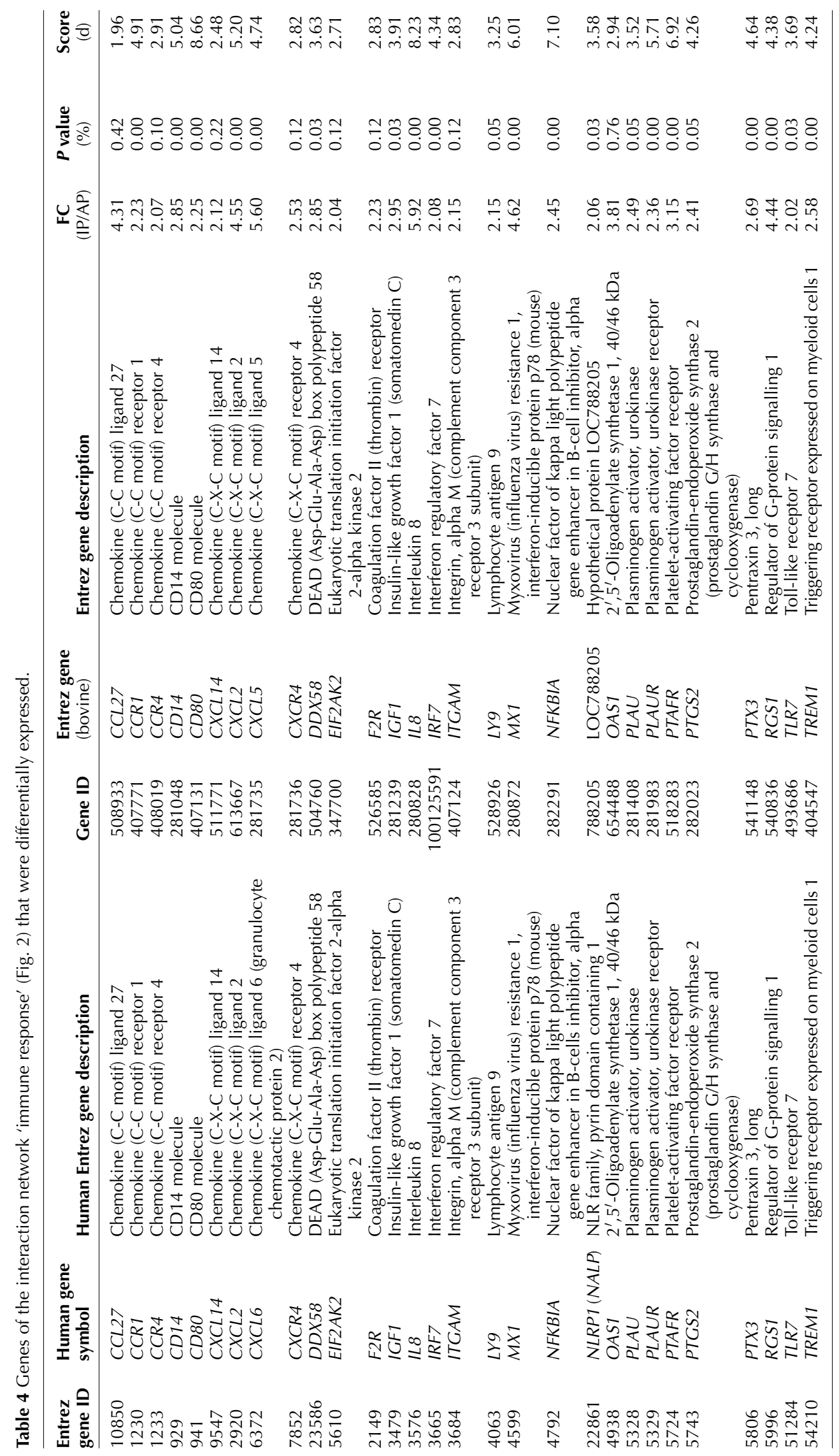




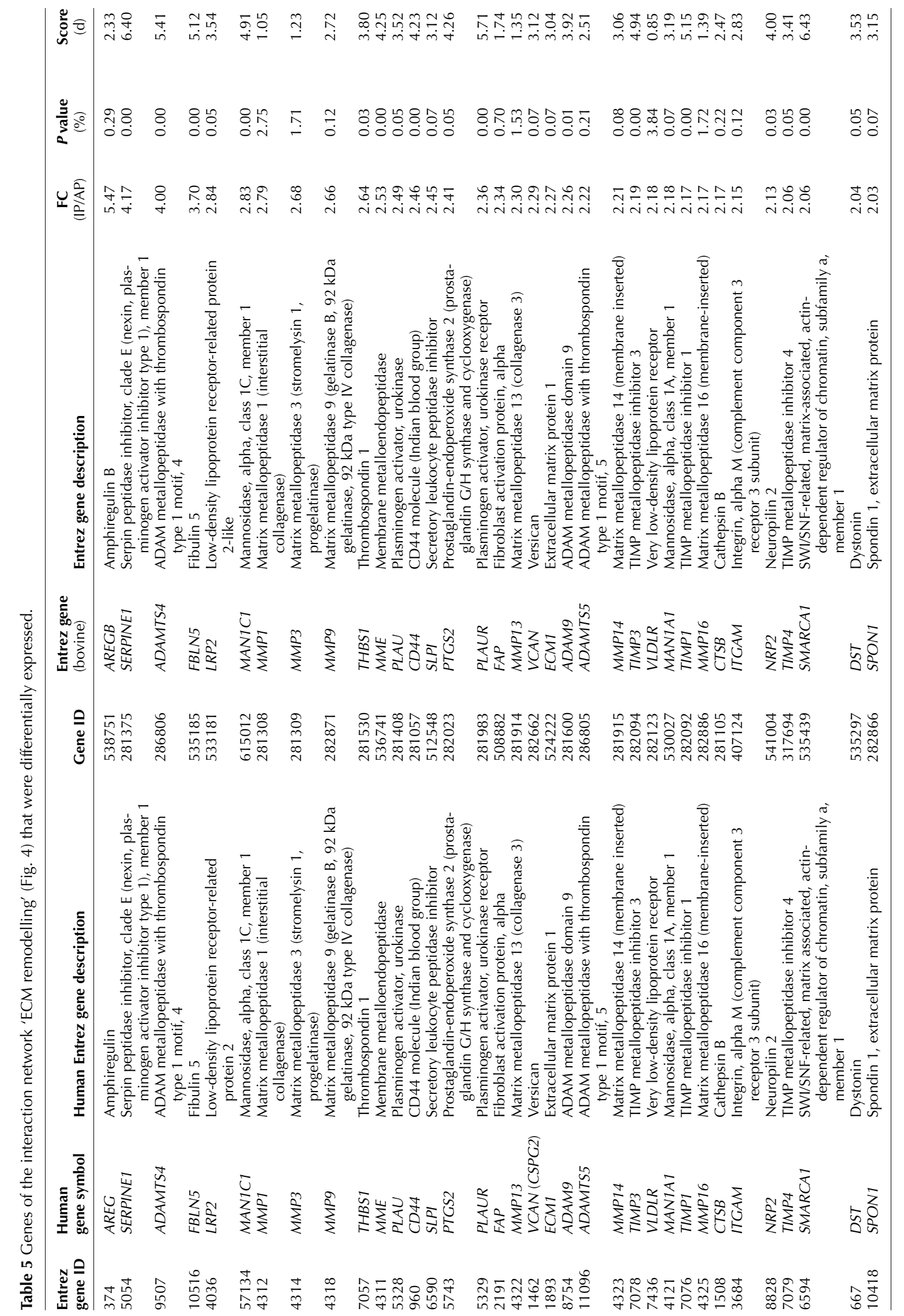




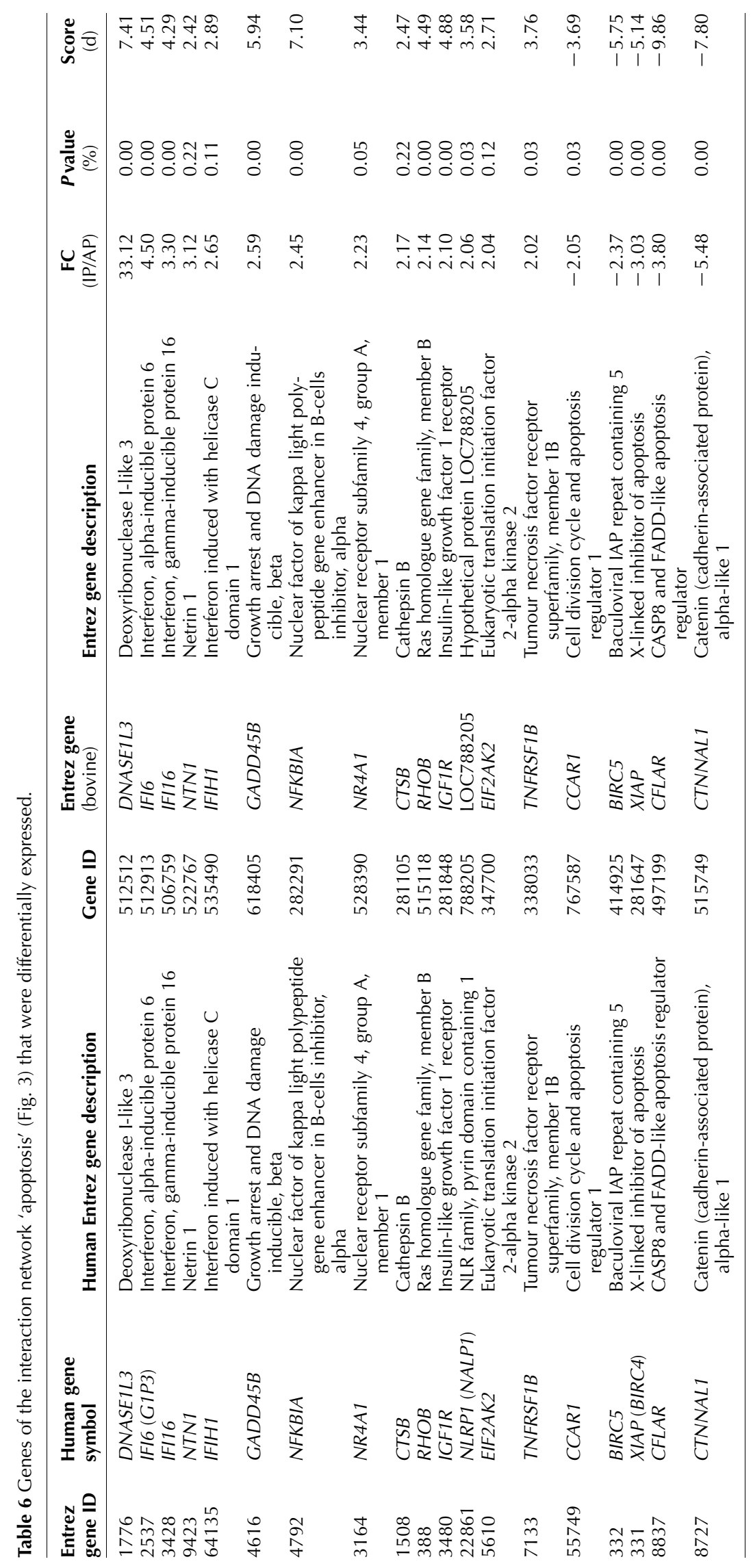



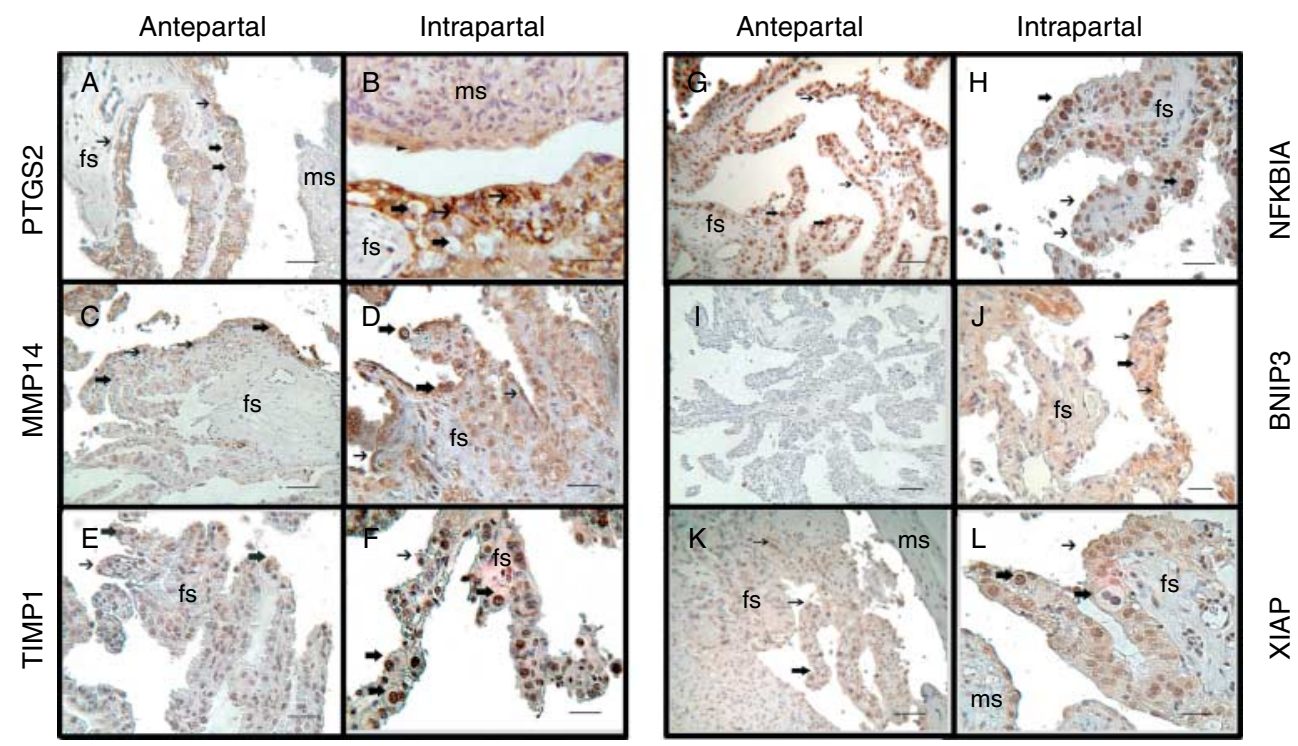

Figure 5 Localisation of expression of selected proteins in antepartum (AP) and intrapartum (IP) placentomes: (A) immunostaining for PTGS2 in AP placentomes: the staining intensity for PTGS2 of the uninucleated trophoblast cells (UNC) was moderate to distinct positive (thin arrows). In contrast, all giant trophoblast cells (GC) were negative (bold arrows). fs, foetal stroma; ms, maternal stroma; sb $=50 \mu$ m; (B) immunostaining for PTGS2 in IP placentomes: strong staining for the antibody against PTGS2 is restricted to the UNC (thin arrows), whereas the TGC are negative (bold arrows). The cytoplasm of caruncular epithelium cells showed a weak to moderate expression for PTGS2 (arrowhead); $s b=50 \mu \mathrm{m}$; $(\mathrm{C})$ immunostaining for MMP14 in AP placentomes: TGC were only weak positive stained or negative (bold arrows), whereas the UNC (thin arrows) expressed MMP14 moderately; $s b=100 \mu \mathrm{m}$; (D) immunostaining for MMP14 in IP placentomes: strong immunostaining signals were detected in the UNC (thin arrows), whereas the TGC exhibit a distinct staining intensity (bold arrows). A distinct to strong expression for MMP14 was localised in the fs cells. $\mathrm{sb}=50 \mu \mathrm{m}$; (E) immunostaining for TIMP1 in AP placentomes: TIMP1 was detected in the UNC (thin arrow) and the TGC (bold arrows) with a weak to distinct staining pattern; $s b=50 \mu \mathrm{m}$; $(\mathrm{F})$ immunostaining for TIMP1 in IP placentomes: the immunostaining for TIMP1 increased in the UNC (thin arrows) and the TGC (bold arrows) to strong positive; $s b=50 \mu \mathrm{m} ;(\mathrm{G})$ immunostaining for NFKBIA in AP placentomes: UNC demonstrated a distinct expression for NFKBIA (thin arrows). In contrast, TGC expressed NFKBIA strong (bold arrows); sb=100 $\mu \mathrm{m}$; $(\mathrm{H})$ immunostaining for NFKBIA in IP placentomes: the immunostaining appeared strong in the UNC (thin arrows) and moderate to distinct in the TGC (bold arrows); $\mathrm{sb}=50 \mu \mathrm{m}$; (I) immunostaining for BNIP3 in AP placentomes: no positive signals for BNIP3 were observed in the UNC and TGC; sb=150 $\mu \mathrm{m}$; (J) immunostaining for BNIP3 in IP placentomes: some UNC (thin arrows) and TGC (bold arrow) demonstrated a weak expression for BNIP3, whereas the staining intensity increased in the uterine stromal cells during birth; $s b=50 \mu \mathrm{m}$; $(\mathrm{K})$ immunostaining for XIAP in AP placentomes: the UNC (thin arrows) and TGC (bold arrow) showed weak to moderate XIAP expression; sb=100 $\mu \mathrm{m}$; (L) immunostaining for XIAP in placentomes of intrapartal cattle: the staining intensity for XIAP was distinct to strong in the UNC (thin arrow) and the TGC (bold arrows). The fs were stained moderate to distinct positive. $\mathrm{sb}=50 \mu \mathrm{m}$.

compared to placentome samples extracted in labour immediately after the end of the expulsion phase of parturition (maximum of $15 \mathrm{~min}$ ). The sampling was done after expulsion of the calf to avoid interference with the expulsion process and induction of RFM. We strictly defined the experimental model to minimise influences that alter physiological parturition including the stage of placental expulsion, like prolonged parturition, hypocalcaemia or low oestrogen levels (Schuler et al. 2002, McNaughton \& Murray 2009). Therefore, gestations as well as the parturition were controlled over the whole period.

During sampling, the foetal part of the placenta was not separated from the maternal part to facilitate detection of transcriptome changes of the whole placental unit. Additionally, contaminations from the counterpart cannot be excluded when placentomes are manually separated. To ensure a similar tissue composition in all samples, systematic random sampling was performed and nine samples from three placentomes were pooled. Estimation of the volume fraction of epithelial cells revealed large variations between individual placentome samples that would lead to much higher variation between animals due to tissue sampling if only a single sample per animal was analysed. As described previously (Mayhew 2008), the sampling method is essential to avoid any bias in generating gene expression data because differences of the tissue composition or localisation of the tissue sampling directly influence the results of gene expression analyses (Wyatt et al. 2005).

\section{Overrepresented functional terms for the genes with higher mRNA levels in AP placentome samples}

Analysis of the mRNAs with higher levels in placentome samples of the AP group revealed strongest overrepresentation of functional categories related to cell 
Table 7 Results of immunohistochemistry analyses (Fig. 5).

\begin{tabular}{|c|c|c|c|c|c|c|}
\hline Antibody & UNC & GC & FS & CE & MS & BV \\
\hline \multicolumn{7}{|l|}{ PTGS2 } \\
\hline Antepartal & $+1++$ & - & - & $-+1+$ & - & + \\
\hline Intrapartal & $++/+++$ & - & $-1-+$ & $-+/+$ & - & + \\
\hline \multicolumn{7}{|l|}{ MMP14 } \\
\hline Antepartal & $+1++$ & $-1-+$ & -+ & + & - & ++ \\
\hline $\begin{array}{l}\text { Intrapartal } \\
\text { TIMP1 }\end{array}$ & & ++ \\
\hline Antepartal & $-+/+$ & $+/++$ & $+/++$ & $-+/+$ & $-/+$ & + \\
\hline \multirow{2}{*}{\multicolumn{5}{|c|}{ NFKBIA }} & $-+/+$ & $+/++$ \\
\hline Antepartal & ++ & $++/+++$ & $-+1+$ & $-+/++$ & -+ & \\
\hline Intrapartal & +++ & $+1++$ & $-+/+$ & $-+/++$ & -+ & -1 \\
\hline \multicolumn{7}{|l|}{ BNIP3 } \\
\hline Antepartal & - & - & - & - & + & - \\
\hline Intrapartal & -+ & -+ & - & - & $++/+++$ & - \\
\hline \multicolumn{7}{|l|}{ XIAP } \\
\hline Antepartal & $-+/+$ & $-+/+$ & + & -+ & - & $+/++$ \\
\hline Intrapartal & $++1+++$ & $++1+++$ & $+1++$ & -+ & - & $+/++$ \\
\hline
\end{tabular}

UNC, uninucleated trophoblast cells; GC, giant trophoblast cells; CE, caruncular epithelium; FS, foetal stroma; MS, maternal stroma; BV, blood vessels ( - negative, -+ weak, + moderate, ++ distinct, +++ strong).

cycle and cell division (e.g. cell cycle, cell division, mitosis, microtubule cytoskeleton, chromosome, etc.). This observation is in line with histochemical studies showing a decrease in (maternal) epithelial proliferation near parturition (Boos et al. 2003). Cellular proliferation and cell death are inversely proportional during gestation and near parturition, where apoptosis increases and proliferation declines (Boos et al. 2003). The functional term 'regulation of apoptosis' was also found in the DAVID analysis, whereas genes with higher mRNA levels in AP were predominantly related to negative regulation of cell death and those with higher levels in IP with positive regulation of cell death. Genes involved in the regulation of apoptosis are discussed in detail. In addition, a large number of genes coding for different transmembrane transporters (e.g. for glucose, amino acids, fatty acids, sodium iodide, potassium/ chloride, zinc, vitamins, neurotransmitters, etc.) were identified. Also a number of genes typically associated with the establishment and maintenance of pregnancy showed higher mRNA levels in the AP samples, e.g. members of the pregnancy-associated glycoprotein family (Pag3, PAG5, PAG6, PAG7, LOC100336184, PAG9, PAG15, PAG17, PAG18 and PAG21) and members of the family of prolactin-related proteins (PRL, PRP-VII, PRP2 and PRP3). Expression of PAGs and PRPs has been described in BNC and a role in placenta formation and differentiation has been postulated (Gootwine 2004, Hashizume 2007, Haig 2008). Down-regulation of these genes might be a result of decreasing number of $\mathrm{BNC}$. The decline in number of $\mathrm{BNC}$ shortly before parturition is typical in cases of physiological release of the foetal membranes (Gross et al. 2001).

\section{Overrepresented functional terms for the genes with higher mRNA levels in IP placentome samples}

Genes related to immune response

Regulation of different pro-inflammatory cytokines is essential for uterus activation and normal parturition (Christiaens et al. 2008). Especially, in the last stage of parturition, pro-inflammatory reactions are essential for proper release of the foetal membranes and for a healthy puerperal stage (Kelly 1996). At the level of mRNA, we found elevated concentrations in the IP placentome samples for mRNAs coding for CD14 molecule (2.8-fold higher), CD36 molecule (thrombospondin receptor; threefold higher), chemokine (C-X-C motif) ligand 2 (CXCL2; 4.9-fold higher), CXCL14 (2.1-fold higher), chemokine (C-C motif) receptor 4 (CCR4; 2.1 -fold), macrophage expressed 1 (MPEG1; 2.5-fold) and macrophage scavenger receptor 1 (MSR $1 ; 2.5$-fold).

Up-regulation of these genes indicates increased numbers of monocytes and/or macrophages (MPEG1 and MSR1) in the IP samples compared with AP placentomes since specific expression in monocytes/ macrophages (e.g. CD14) or in macrophages (CXCL14) has been shown (Oliveira \& Hansen 2009). Also for MPEG1 and MSR1, macrophage-specific expression has been shown (Spilsbury et al. 1995 PMID: 7888681, Freeman 1990 PMID: 1978939). A functional role of bovine placental macrophages during parturition for the release of foetal membranes has been suggested by Miyoshi et al. (2002). Oliveira \& Hansen (2009) demonstrated that CD14(+) and CD68(+) macrophages are located in the maternal crypts but not in the foetal part of the placentome. CD14 is an important binding protein for lipopolysaccharides of Escherichia coli, the typical pathogen in the post partum uterus 
(Sheldon et al. 2008). In addition to its role in innate immune responses to bacterial and other microbial structures, CD14 also functions as a receptor involved in the recognition and phagocytosis of cells undergoing apoptosis (Gregory 2000). Thus, the role of endometrial macrophages could be on one side clearing of apoptotic cells and pathogen defence after parturition.

Nuclear factor kappa B (NFKB) is a key transcription factor that regulates transcription of, e.g. different cytokine genes involved in inflammatory reactions, such as TNFA, IL1 and also expression of PTGS2 (Baeuerle \& Baichwal 1997). The activity of NFKB is regulated by several specific inhibitors such as NFKB inhibitor alpha (NFKBIA), which prevents translocation of NFKB to the nucleus (Baeuerle 1998). In the presented study, a 2.4-fold higher expression of NFKBIA was observed in IP placentomes. On protein level, staining intensity in UNC was higher in IP samples. Interestingly, distinct staining was found in or around caruncular blood vessels of AP samples but not in IP placentomes. This result could indicate a differential regulation of leukocyte infiltration of the placentomes, via NFKB regulation.

Macrophages have been shown to be the major producers of pro-inflammatory cytokines like interleukin 1 beta (IL1B) and tumour necrosis factor alpha (TNFA) as well as the chemokine IL8, which were described as essential regulatory mediators during labour (Elliott et al. 1998, Goldenberg et al. 2000). For IL8, higher mRNA levels (5.9-fold higher) were found in IP placentomes. IL8 is one of the major mediators of the inflammatory response and has been shown both to attract and to activate PMNs (Colditz et al. 1989), the most prominent postpartal uterine immune cells. It has been demonstrated that IL8 can be produced by many cell types, e.g. macrophages, endothelial cells and even phagocytising PMNs (Bazzoni et al. 1991). IL8 expression is downregulated during gestation by high progesterone $\left(\mathrm{P}_{4}\right)$ concentrations (Barclay et al. 1993, Kelly et al. 1994). In human placenta, IL8 production is increased after spontaneous labour and was localised in the perivascular area of foetal vessels in third-trimester placenta (Elliott et al. 1998). The increase in IL8 mRNA levels corresponds to the influx of PMNs and other immune cells like macrophages that has been found immediately before parturition (Yellon et al. 2003) and its known synergism with the effects of $\mathrm{PGE}_{2}$ in attracting PMNs to skin sites (Foster et al. 1989, Colditz 1990) suggests a possible role for IL8 in initiation and progression of labour through activation of PMNs, which release proteolytic enzymes, such as collagenases and elastases that degrade ECM contributing together with apoptosis to foetal membrane rupture (Osmers et al. 1992, Winkler \& Rath 1996, Moore et al. 2006).

In the context of prostaglandin metabolism, two mRNAs coding for prostaglandin synthases, namely hydroxyprostaglandin dehydrogenase 15-(NAD;
HPGD) and PTGS2 (alias COX2), were identified as up-regulated in the IP placentome samples (HPGD: 2.4fold, PTGS2: 2.4-fold). PTGS2 protein was mainly detectable in the uninuclear trophoblast cells but also to a lesser extent in the caruncular epithelium and blood vessels. This is in line with investigations of the PTGS2 expression around parturition (Whittle et al. 2000) and its essential role in the production of prostaglandins $\mathrm{PGF}_{2 \alpha}$ and $\mathrm{PGE}_{2}$, which are involved in the regulation of every step of parturition: membrane rupture, cervical dilatation, myometrial contractility, placental separation and uterine involution (Olson et al. 1995). Myometrial contractions at parturition are a product of uterine activation and increased levels of genes involved in this process, including PTGS2 and HPGD (Olson 2003, Mendelson 2009), also described as uterine activation proteins (UAPs). An additional indication for the activation of the innate immune system was found by up-regulation of many typical interferon-induced genes (e.g. interferon-induced protein 44 like (IFI44; 4.8-fold higher) and interferon induced with helicase $\mathrm{C}$ domain 1 (IFIH1; 2.7-fold higher)) and of members of the complement system (e.g. complement component 1, $r$ subcomponent $(C 1 R ; 2.2$-fold higher) and complement component 7 ( $C 7$; 3.6-fold higher).

Remodelling of the extracellular matrix and regulation of angiogenesis

DAVID analysis also revealed enrichment of genes coding for proteins involved in ECM remodelling for the mRNAs with higher levels in IP placentome samples. The main groups of these genes were i) matrix metallopeptidases: MMP1, MMP3, MMP9, MMP13, MMP14 and MMP16; ii) TIMP metallopeptidase inhibitors: TIMP1, TIMP3 and TIMP4 and iii) ADAM metallopeptidases: ADAM9, ADAM19, ADAMDEC1, ADAMTS4, ADAMTS5 and ADAMTSL4. The up-regulation of MMP2 and MMP9 protein in relation to onset of labour has been described in various species (Ulug et al. 2001, Walter \& Boos 2001, Goldman \& Shalev 2003, Takagi et al. 2007). Especially, the up-regulation of MMP9 protein, partially released by PMNs in the foetal membranes (Osmers et al. 1995) with beginning contractions (Tsatas et al. 1999, Goldman \& Shalev 2003), is linked to the rupture of the foetal membranes implicating an important role in placental separation. MMP9 degrades type IV and V collagens and has been shown to be present in tertiary granules of neutrophils and MMP9 release can be induced by IL8 via activation of chemokine (C-X-C motif) receptor 2 (CXCR2; Chakrabarti \& Patel 2005). Additionally, the expression of MMP9 is regulated by a PTGS2-PGE 2 EP4 receptor axis in macrophages. Macrophages are able to secrete active MMP9 after exposure to MMP1 or MMP3; both of them are up-regulated in the IP group (2.8- and 2.7-fold respectively). These exposures also triggered 
a quick release of TNFA, which could be blocked by inhibitors of MMP1 and MMP3 (Steenport et al. 2009). Pro-MMP9 is also activated by MMP3 and indirectly by MMP14 (on protein levels also detected, see Fig. 5 and Table 7), which activates MMP13 that also cleaves proMMP9 (Pap et al. 2000, Elnemr et al. 2003, Dreier et al. 2004). The localisation and the increase in MMP14 protein in IP samples (foetal stroma, UNC) is in line with recent findings and gives additional hints about the importance of MMP14 in the process of foetal membrane release (Dilly et al. 2011).

Furthermore, plasminogen activator, urokinase (PLAU), whose mRNA is also up-regulated (2.5-fold) in IP samples, is known to play a major role in degradation of ECM (Tsatas et al. 1999). The function of PLAU is to convert plasminogen to plasmin, which subsequently activates MMPs, such as MMP3 and MMP9. PLAU is also able to directly activate MMP9 (Zhao et al. 2008). The simultaneous up-regulation of PLAU receptor (PLAUR, 2.4-fold) mRNA and serpin peptidase inhibitor, clade $\mathrm{E}$ (nexin, plasminogen activator inhibitor type 1 ), member 1 (SERPINE1, 4.2-fold) mRNA indicates tight regulation of ECM degradation in the placentomes immediately after expulsion of the calf. Interestingly, prostaglandins $\mathrm{PGE}_{2}$ and $\mathrm{PGF}_{2 \alpha}$ are also able to increase the expression of MMPs, especially MMP2 and MMP9, and therefore the production of prostaglandins by PTGS2 (also up-regulated in IP samples) could play a role in the separation and release of the placenta (Weinreb et al. 1997, Yoshida et al. 2002). MMP16 (2.2-fold up-regulated) is an activator of pro-MMP2 and it could be demonstrated that the activation of proMMP2 is enhanced by TIMP3 (2.2-fold) and by TIMP2 (Zhao et al. 2004). A disintegrin and metallopeptidases (ADAMs) and ADAMs with thrombospondin motifs (ADAMTS) are membrane-bound peptidases closely related to MMPs. These multifaceted molecules bear metallopeptidase and disintegrin domains endowing them with features of both peptidases and adhesion molecules. Peptidases of the ADAM family are associated with various physiological and pathological processes like trophoblast invasion and matrix degradation during pregnancy, angiogenesis and inflammation, neurodegeneration and fibrosis, through shedding of the apoptosis-inducing FAS ligand (van Goor et al. 2009). It was shown that catalytically active ADAM9 (2.3-fold), together with ADAM15 and ADAM17, is associated with CD68 + monocytes derived cells in inflammatory tissues (Oksala et al. 2009). Since MMPs and ADAMs are very potent collagenases, they have to be tightly regulated to avoid uncontrolled tissue damage. Three mRNAs for inhibitors of different MMPs, TIMP1, TIMP3 (both 2.2-fold) and TIMP4 (2.1-fold) were also identified as up-regulated in the IP placentome samples. TIMP1 is the direct inhibitor of MMP1 (Vallon et al. 1997). Strongest expression of TIMP1 protein was detected in GC (TGC) but also in all other areas of the placentomes. Except for foetal stroma, staining intensity was always higher in IP samples, which correlates with up-regulation of TIMP1 mRNA in IP samples. The broad expression could indicate a regulatory function in finetuning the activity of MMPs such as MMP1, MMP2 and MMP3. It has been shown for TIMP3 that expression is strictly balanced with expression of MMP9 during early gestation in the mouse (Teesalu et al. 1999). The process of parturition is also associated with the regulation of vascular remodelling-related genes like SERPINE1, FBLN5, thrombospondin 1 (THBS1; 2.6-fold; Haddad et al. 2008), angiopoietin 2 (ANGPT2; 4.4-fold) and angiopoietin-like 4 (ANGPTL4; 2.7 -fold). This process of remodelling is also represented by the differential regulation of different genes all described to be involved in the process of angiogenesis and regulation of angiogenesis (e.g. fibroblast growth factor 2 (basic; FGF2; 2.3-fold), platelet/endothelial cell adhesion molecule (PECAM1; 2.3-fold), vascular endothelial growth factor A (VEGFA; -2.7-fold) and vasohibin 2 (VASH2; - 2.4-fold)). Interestingly, VEGFA mRNA has lower levels in IP samples, which could be a mechanism to reduce vascular permeability (Zachary 1998, Farmer et al. 2002). Since many genes involved in the biological processes of ECM remodelling were also described in the context of angiogenesis, the regulation of vascular remodelling could also play a role in the release of foetal membranes.

\section{Apoptosis-related genes}

DAVID analysis showed enrichment for apoptosisrelated genes for both the IP up-regulated and the IP down-regulated genes. The majority of the genes with lower levels in the IP placentome samples are known or assumed to have negative effects on apoptosis whereas the genes with increased mRNA levels are predominantly positive regulators of programmed cell death. Apoptosis has been shown to be an essential process during the release of the foetal membranes and maturation of the placenta before parturition (Boos et al. 2003, Keelan et al. 2003). The observed up-regulation of typical monocyte/macrophage markers in IP placentomes could also be associated with increased apoptosis in the placentomes, since macrophages play an important role in clearance of apoptotic cells (Erwig \& Henson 2007). In addition to pro-apoptotic signals, the reduction of the blood supply to the placenta after umbilical cord rupture could be a possible reason for induction of apoptosis (Runic et al. 1998, McLaren et al. 1999). One important gene family involved in the regulation of apoptosis is the TNF receptor family (Baker \& Reddy 1998). For two members of this gene family, namely TNF receptor superfamily, member 1B (TNFRSF1B; twofold) and TNF receptor superfamily, member $6 \mathrm{~b}$, decoy (TNFRSF6B; 4.2-fold) higher mRNA levels were found in IP placentomes. Furthermore, a number of 
genes associated with the TNF signalling pathway were down-regulated in IP placentome samples, such as TNF receptor-associated factors 3 and 6 (TRAF3, TRAF6; -3.3-fold, -2.1-fold), Fas (TNFRSF6)-associated via death domain (FADD; -2.6 -fold) and Fas-associated factor family member 2 (FAF2; -3.3 -fold). Some of the mRNAs with higher levels in the IP group compared with the AP group are growth arrest and DNA damageinducible, beta (GADD45B), BNIP3; DnaJ (Hsp40) homologue, subfamily $\mathrm{A}$, member 3 (DNAJA3), eukaryotic translation initiation factor 2 -alpha kinase 2 (EIF2AK2; Table 7 and Supplementary Figure 1, see section on supplementary data given at the end of this article for the corresponding protein detections). Increased expression of BNIP3 protein in UNC, GC and uterine stromal cells during birth could indicate increased apoptosis since BNIP3 a pro-apoptotic factor of the Bcl-2 family was localised in IP maternal stroma. The presence of this protein was also shown in human placenta (Stepan et al. 2004). The expression of it is associated with hypoxic situation, e.g. in necrotic regions of malignant tumours (Sowter et al. 2001).

Genes with lower levels in IP samples that are associated with cell survival and anti-apoptotic functions are, e.g. CASP8 and FADD-like apoptosis regulator (CFLAR; -3.8-fold), cell death-inducing DFFA-like effector A (CIDEA; -4.8-fold) and XIAP (-3-fold; Table 7 and Supplementary Figure 1, see section on supplementary data given at the end of this article for the corresponding protein detections). In contrast to the findings of gene expression, expression of XIAP protein, a known inhibitor of apoptosis (Straszewski-Chavez et al. 2004), was higher in IP samples. However, mRNA expression was only analysed in two time points and the expression profile between these time points is not known, and the half-life of mRNA and protein is different. Interestingly, XIAP was found in all different parts of the placentome (UNC, GC, CE and BV) except for the maternal stroma, where BNIP3 expression was found. This indicates complex spatial regulation of apoptosis in the placentome during birth.

This study is the first systematic analysis of differential gene expression of bovine placentome samples collected from contact zones before parturition compared with the time immediately after expulsion of the calf. Figure 6 summarises the findings of this study to illustrate the complex processes in the placentome during birth. The identified transcriptome changes and protein localisations revealed a complex regulation and interaction of immune system-related processes, vascular, tissue and ECM remodelling, and apoptosis. Particularly, the identified immune-related genes suggest an important role of inflammatory cells, such as macrophages and neutrophils, in the process of release of foetal membranes. Furthermore, the results of this study provide a basis for investigations of the pathophysiology of disturbed release of foetal membranes.

\section{Materials and Methods}

\section{Animal model}

Each experimental group (AP and IP) consisted of four cows (Bos taurus; Simmental breed), with two primiparous and two polyparous in the second or third pregnancy. None of the polyparous animals suffered from RFM in earlier calvings. All pregnancies were monitored by regular clinical examinations, and blood samples were taken and investigated to

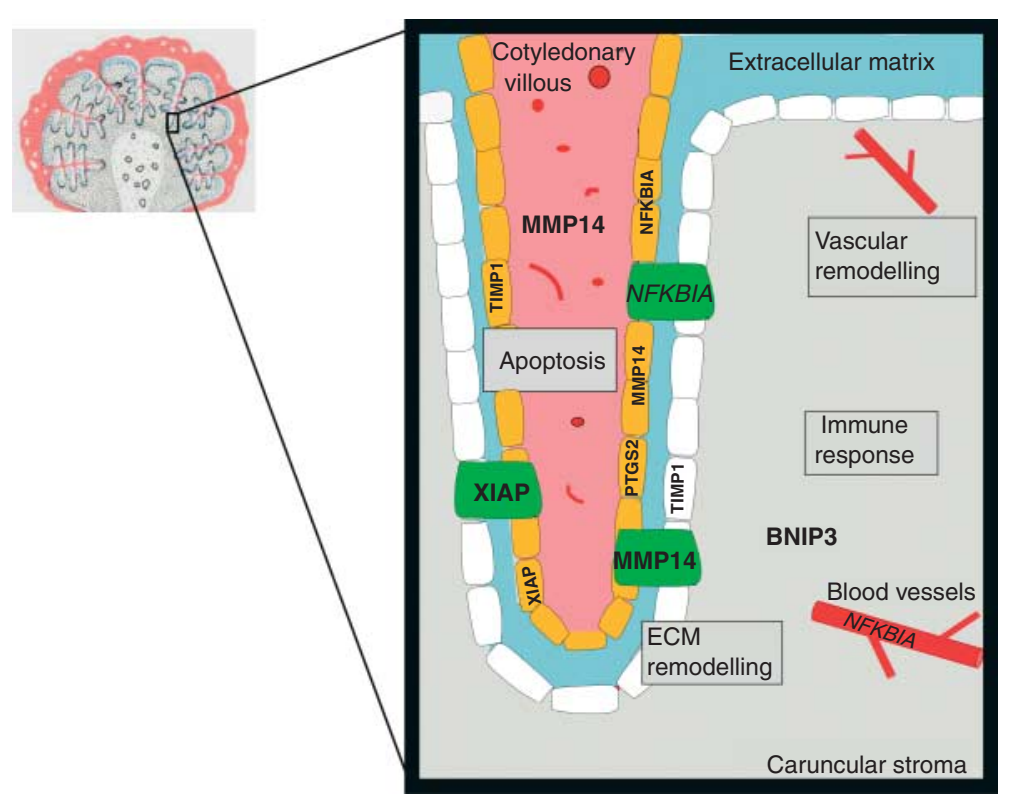

Figure 6 Scheme demonstrating the findings of this microarray study. The foetal maternal contact zone is shown exemplarily. In the boxes (light grey) biological processes, to which genes in the IP group are associated with: apoptosis, ECM remodelling, vascular remodelling and immune response. The locations of the proteins according to the results of immunohistochemistry (Table 7). Proteins with stronger appearance IP (in bold) and AP (in italic). Light blue: extracellular matrix; orange: uninucleated trophoblast cells; rose: cotyledonary villous, including foetal stroma; red: blood vessels; green: giant trophoblast cells; white: caruncular epithelium; light grey: caruncular stroma. 
exclude predisposing factors of dystocia or RFM, such as subclinical hypocalcaemia or ketosis. Plasma $\mathrm{P}_{4}$ levels were determined (Prakash et al. 1987), which were stable throughout the last 3 weeks of gestation $(>2 \mathrm{ng} / \mathrm{ml})$. Animals of the AP group underwent caesarean section $272 \pm 3$ days after artificial insemination (AI). The animals of the IP group calved $288 \pm 7$ days after AI. In all IP animals, parturition occurred physiologically without any problems and the foetal membranes were delivered in $<6 \mathrm{~h}$ after calving.

All experiments with animals were conducted with permission from the local veterinary authorities and in accordance with the accepted standards of humane animal care.

\section{Tissue sampling}

After rupture of the umbilical cord, three placentomes per animal were collected. In the AP group, the placentomes were collected under visual control. In the IP group, the placentomes were recovered transvaginally by using an effeminator by Reisinger (Heuwieser et al. 1985) within 15 min after rupture of the umbilical cord. The tissue sampling was done systematically (Herbach et al. 2005; Fig. 1) as follows: the placentomes were analysed as a foeto-maternal unit, therefore maternal and foetal parts were not separated. Every placentome was cut perpendicular to the luminal surface in $0.5 \mathrm{~cm}$-thick slices, which were placed with the right cut surface facing downwards on a sterile RNase-free surface. The slices were covered with a grid $(1 \times 1 \mathrm{~cm})$ and every point hitting the visual foeto-maternal connection was counted. These connecting points were divided by three resulting in $n=x$, and a random number between 1 and $x$ was determined, where tissue samples were collected. Tissue cuboids $(\sim 0.6 \times 0.6 \times 1.0 \mathrm{~cm})$ were cut out and divided into three parts of $\sim 0.2 \times 0.2 \times 0.3 \mathrm{~cm}$. The middle part was transferred into RNAlater (Ambion, Huntingdon, Cambridgeshire, UK), incubated overnight at $4{ }^{\circ} \mathrm{C}$ and then stored at $-20^{\circ} \mathrm{C}$ until further processing. The other samples were fixed in formalin $(3.7 \%)$ and paraformaldehyde $(4.2 \%)$, respectively, and routinely processed and embedded in paraffin.

\section{Morphometric analysis}

Sections were stained with haematoxylin and eosin (H\&E) and evaluated using unbiased model-independent stereological methods as described (Herbach et al. 2005). Morphometric evaluation was carried out on a Videoplan image analysis system (Zeiss-Kontron, Eching, Germany) attached to a microscope by a colour video camera. Images were displayed on a colour monitor at a $850 \times$ final magnification, and the profiles of placentomes, epithelial cells and non-epithelial cells were measured planimetrically by circling their contours with a cursor on the digitising tablet of the image analysis system. The volume density of epithelial cells in the placentomes $\left(V_{(\text {Epithelial cells/Placentome) }}\right)$ was calculated by dividing the sum of cross-sectional areas of epithelial cells by the sum of crosssectional areas of the placentome, the volume density of other

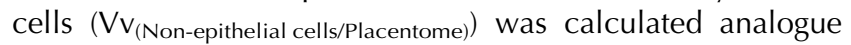
to the $\mathrm{VV}_{\text {(Epithelial cells/Placentome). }}$. The morphometric data were analysed by a Kruskal-Wallis test (SPSS 15.0; IBM Corporation, Armonk, NY, USA).

\section{Microarray hybridisation and data analysis}

Total RNA was isolated from the tissue samples of the placentomes using Trizol Reagent (Invitrogen $\mathrm{GmbH}$ ) according to the manufacturer's instructions. Tissue samples $(n=3)$ of individual placentomes $(n=3)$ were pooled before isolation of the RNA. Quantity and quality of total RNA were determined by spectrometry and agarose gel electrophoresis. For every animal, equal amounts of total RNA of the single placentomes $(n=3)$ were pooled for microarray analysis. Preparation of hybridisation probes for Affymetrix GeneChip Bovine Genome Arrays (Affymetrix, Santa Clara, CA, USA) started from $10 \mu \mathrm{g}$ total RNA and was done using the One-Cycle Target Labelling and Control Reagent package (Affymetrix). For the hybridisation, wash and staining processes, the GeneChip Hybridization, Wash and Stain Kit (Affymetrix) was used. All steps were done according to the manufacturer's protocol. The processed arrays were scanned with a GeneChip Scanner $30007 \mathrm{G}$ with AutoLoader (Affymetrix).

Affymetrix CEL files were processed using log scale robust multi-array analysis (RMA; Irizarry et al. 2003). Quality control was done using different BioConductor tools, such as pseudo images (BioC package AffyPLM), RNA degradation plots (BioC package Affy), box plots, distance matrices and heatmaps. After RMA processing probe sets were filtered based on expression calls. Only such probe sets were used that had present calls in at least three of four samples in at least one of the experimental groups. Significance analysis was performed using the 'significance analysis of microarrays method' (SAM, two-class unpaired; Tusher et al. 2001). If a transcript was represented on the array by more than one probe set, the mean signal ratio was calculated.

Identification of quantitatively enriched functional categories was done using the 'Functional annotation clustering' tool of the DAVID (Dennis et al. 2003). The text-mining tool CoPub (Frijters et al. 2008) was used to identify biological keywords associated with the differentially expressed genes. These analyses were all based on the Entrez Gene ID of the putative human orthologous genes. Interaction networks were built for genes of selected functional groups using Pathway Architect software (version 3.0.1, Stratagene, Heidelberg, Germany). Most of the interactions and cellular localisations provided by the Pathway Architect databases were checked. Additional interactions found in the literature were assigned to the network.

\section{Quantitative real-time $R T$-PCR}

The same RNA samples as for microarray analysis were used for quantitative real-time RT-PCR (qPCR). First-strand cDNA was synthesised starting from $1 \mu \mathrm{g}$ total RNA with the Sprint RT Complete-Double PrePrimed $(6 \times 8$ well) kit (Takara Bio Europe/Clontech, Saint-Germain-en-Laye, France). qPCR was performed on a StepOne Real-Time PCR System, 48-well (Applied Biosystems, Langen, Germany) by the use of the Power SYBR Green PCR Master Mix (Applied Biosystems) or the FastStart Universal SYBR Green Master (Rox; Roche) in 
Table 8 Antibodies for immunohistochemistry.

\begin{tabular}{|c|c|c|c|c|}
\hline $\begin{array}{l}\text { Primary antibody dilution, } \\
\text { incubation time, } \\
\text { incubation temperature }\end{array}$ & Clonality & $\begin{array}{l}\text { Secondary antibody dilution, } \\
\text { incubation time, incubation } \\
\text { temperature }\end{array}$ & $\begin{array}{l}\text { Company } \\
\text { primary } \\
\text { antibody }\end{array}$ & $\begin{array}{l}\text { Company } \\
\text { secondary } \\
\text { antibody }\end{array}$ \\
\hline PTGS2 $1: 400,20 \mathrm{~h}, 6^{\circ} \mathrm{C}$ & Polyclonal & Anti-goat IgG rabbit $1: 400,30 \mathrm{~min}, \mathrm{rt}$ & Abcam plc & $\begin{array}{l}\text { Dako Deutschland } \\
\text { GmbH }\end{array}$ \\
\hline MMP14 1:50, $20 \mathrm{~h}, 6{ }^{\circ} \mathrm{C}$ & Monoclonal & Anti-mouse IgG rabbit 1:300, $30 \mathrm{~min}, \mathrm{rt}$ & & \\
\hline TIMP1 1:100, $20 \mathrm{~h}, 5^{\circ} \mathrm{C}$ & Polyclonal & Anti-rabbit IgG swine, 1:300, $30 \mathrm{~min}$, rt & & \\
\hline NFKBIA $1: 100,20 \mathrm{~h}, 5^{\circ} \mathrm{C}$ & Polyclonal & Anti-rabbit IgG swine, $1: 300,30 \mathrm{~min}$, rt & & \\
\hline BNIP3 $1: 400,20 \mathrm{~h}, 6^{\circ} \mathrm{C}$ & Monoclonal & Anti-mouse IgG rabbit $1: 300,30 \mathrm{~min}$, rt & & \\
\hline XIAP $1: 100,20 \mathrm{~h}, 5^{\circ} \mathrm{C}$ & Polyclonal & Anti-rabbit IgG swine, 1:300, $30 \mathrm{~min}$, rt & $\begin{array}{r}\text { Abnova GmbH } \\
\text { c/o EMBLEM }\end{array}$ & \\
\hline
\end{tabular}

rt, room temperature.

a final volume of $20 \mu \mathrm{l}$. Primer sequences are shown in Supplementary Table 1 , see section on supplementary data given at the end of this article. Annealing temperature was $60{ }^{\circ} \mathrm{C}$ for all PCRs. As control for DNA contamination, RNA without RT was used as PCR template ( - RT control). The cycle number $\left(C_{\mathrm{T}}\right)$ required to achieve a definite SYBR Green fluorescence signal ( $C_{\mathrm{T}}$ threshold) was calculated (StepOne Software v2.1, Applied Biosystems). The $C_{\mathrm{T}}$ is correlated inversely with the logarithm of the initial template concentration. The $C_{\mathrm{T}}$ determined for the target genes was normalised against the housekeeping genes RPS23 and PPP2R5B $\left(\Delta C_{\mathrm{T}}\right.$; Livak \& Schmittgen 2001). Relative expression difference between the IP and the AP samples was calculated from the difference of the mean $C_{\mathrm{T}}$ values $\left(\Delta \Delta C_{\mathrm{T}}\right)$. All PCR fragments were analysed on a DNA1000 Labchip (Agilent Technologies, Waldbronn, Germany) to check amplification of a single product and sequenced to verify the obtained PCR product.

\section{Immunohistochemistry}

For immunohistochemical studies, $5 \mu \mathrm{m}$ serial sections of each placentome sample were collected on slides (SupraFrost Ultra Plus, Menzel-Gläser; Gerhard Menzel Glasbearbeitungswerk $\mathrm{GmbH} \&$ Co KG, Braunschweig, Germany), which were coated with aminopropyltriethoxysilane. Sections were preincubated with proteinase XXIV $0.1 \%$ (Sigma, P8038) for 15 min and washed with PBS buffer $\mathrm{pH} \mathrm{7.4.} \mathrm{Endogenous}$ peroxidase activity was blocked with $0.1 \% \mathrm{H}_{2} \mathrm{O}_{2}$ at room temperature for $10 \mathrm{~min}$.

Antigen localisation was achieved using the avidinbiotin complex technique (ABC-technique; Hsu et al. 1981) according to the following protocol. Paraffin sections $(5 \mu \mathrm{m})$ were dewaxed and subjected to the following immunohistochemical staining schedule: i) elimination of endogenous peroxidase activity with $0.5 \% \mathrm{H}_{2} \mathrm{O}_{2}$ in PBS for 15 min at $20{ }^{\circ} \mathrm{C}$; ii) elimination of non-specific protein binding by incubation at $20^{\circ} \mathrm{C}$ with $10 \%$ normal goat serum for $1 \mathrm{~h}$; iii) incubation overnight at $4{ }^{\circ} \mathrm{C}$ with one of the following

Table 9 Non-specific antibodies for isotype controls for immunohistochemistry.

\begin{tabular}{lll}
\hline Goat $\lg \mathrm{G}$ & Purified (UNLB) & BiOZOL Diagnostica \\
Mouse $\operatorname{lgG}_{2 b}$ & \\
Mouse $\operatorname{lgG}_{3}$ & \\
Rabbit lgG & \\
\hline
\end{tabular}

primary antibodies (Table 7) against PTGS2, MMP14, TIMP 1, NFKBIA, BNIP3 and XIAP; iv) incubation with a corresponding secondary biotin-conjugated antibody (Table 8); v) incubation with HRP-conjugated $\mathrm{ABC}$ for $1 \mathrm{~h}$ at $20^{\circ} \mathrm{C}$ and vi) treatment with $0.05 \mathrm{mg} / \mathrm{ml}$ diaminobenzidine in PBS. Sections were left unstained or counterstained in Mayer's haematoxylin, dehydrated and mounted with DePeX Eukitt (Riedel de Haen, Seelze, Germany).

Protein Block Serum-Free solution (Dako, X0909, Hamburg, Germany) was used to inhibit non-specific staining of primary and secondary antibodies during the immunohistochemical detection of antigens. As negative control, buffer (Dako) was used instead of the specific primary antibody. As positive controls, tissues were used, which is known to show specific immunostaining with the antibodies used in this study. For further negative control experiments, non-specific antibodies (Table 9) diluted to the same final protein concentration like the used specific antibodies were substituted for the primary antibodies.

The used non-specific antibodies were matched to the host species and isotype of the specific antibodies.

\section{Supplementary data}

This is linked to the online version of the paper at http://dx.doi. org/10.1530/REP-11-0204.

\section{Declaration of interest}

The authors declare that there is no conflict of interest that could be perceived as prejudicing the impartiality of the research reported.

\section{Funding}

This project was supported by $\mathrm{H}$ W Schaumann foundation and - in part - by the BMBF-funded project Phenomics.

\section{Acknowledgements}

We wish to extend our thanks to the staff of the Clinic for Ruminants for their support, to the staff of the Lehr und Forschungsgut (LFG) Achselschwang for their support in this work. Special thanks also to Andrea Klenner and the members of the LAFUGA for their help and support. 


\section{References}

Baeuerle PA 1998 Pro-inflammatory signaling: last pieces in the NF-kappa B puzzle. Current Biology8 R19-R22. (doi:10.1016/S0960-9822(98)70010-7)

Baeuerle PA \& Baichwal VR 1997 NF-kappa B as a frequent target for immunosuppressive and anti-inflammatory molecules. Advances in Immunology 65 111-137. (doi:10.1016/S0065-2776(08)60742-7)

Baker SJ \& Reddy EP 1998 Modulation of life and death by the TNF receptor superfamily. Oncogene 17 3261-3270. (doi:10.1038/sj.onc.1202568)

Barclay CG, Brennand JE, Kelly RW \& Calder AA 1993 Interleukin-8 production by the human cervix. American Journal of Obstetrics and Gynecology 169 625-632.

Bazzoni F, Cassatella MA, Rossi F, Ceska M, Dewald B \& Baggiolini M 1991 Phagocytosing neutrophils produce and release high amounts of the neutrophil-activating peptide 1/interleukin 8. Journal of Experimental Medicine 173 771-774. (doi:10.1084/jem.173.3.771)

Björkman NH 1954 Morphological and histochemical studies on the bovine placenta. Acta Anatomica 22 1-91.

Björkman NH \& Sollen P 1960 Morphology of bovine placenta at normal delivery. Acta Veterinaria Scandinavica 1 157-177.

Boos A, Janssen V \& Mulling C 2003 Proliferation and apoptosis in bovine placentomes during pregnancy and around induced and spontaneous parturition as well as in cows retaining the fetal membranes. Reproduction 126 469-480. (doi:10.1530/rep.0.1260469)

Chakrabarti S \& Patel KD 2005 Regulation of matrix metalloproteinase-9 release from IL-8-stimulated human neutrophils. Journal of Leukocyte Biology 78 279-288. (doi:10.1189/jlb.1004612)

Christiaens I, Zaragoza DB, Guilbert L, Robertson SA, Mitchell BF \& Olson DM 2008 Inflammatory processes in preterm and term parturition. Journal of Reproductive Immunology 79 50-57. (doi:10.1016/j.jri.2008. 04.002)

Colditz IG 1990 Effect of exogenous prostaglandin $E_{2}$ and actinomycin D on plasma leakage induced by neutrophil-activating peptide-1/ interleukin-8. Immunology and Cell Biology 68 397-403. (doi:10. 1038/icb.1990.53)

Colditz I, Zwahlen R, Dewald B \& Baggiolini M 1989 In vivo inflammatory activity of neutrophil-activating factor, a novel chemotactic peptide derived from human monocytes. American Journal of Pathology 134 755-760.

Dennis G Jr, Sherman BT, Hosack DA, Yang J, Gao W, Lane HC \& Lempicki RA 2003 DAVID: database for annotation, visualization, and integrated discovery. Genome Biology 4 P3. (doi:10.1186/gb-20034-5-p3)

Dilly M, Hamburch N, Shenavai S, Schuler G, Froehlich R, Haeger JD, Ozalp GR \& Pfarrer C 2011 Expression of matrix metalloproteinase (MMP)-2, MMP-14 and tissue inhibitor of matrix metalloproteinase (TIMP)-2 during bovine placentation and at term with or without placental retention. Theriogenology 75 1104-1114. (doi:10.1016/ j.theriogenology.2010.11.019)

Dreier R, Grassel S, Fuchs S, Schaumburger J \& Bruckner P 2004 Pro-MMP-9 is a specific macrophage product and is activated by osteoarthritic chondrocytes via MMP-3 or a MT1-MMP/MMP-13 cascade. Experimental Cell Research 297 303-312. (doi:10.1016/ j.yexcr.2004.02.027)

Elliott CL, Kelly RW, Critchley HO, Riley SC \& Calder AA 1998 Regulation of interleukin 8 production in the term human placenta during labor and by antigestagens. American Journal of Obstetrics and Gynecology 179 215-220. (doi:10.1016/S0002-9378(98)70275-3)

Elnemr A, Yonemura Y, Bandou E, Kinoshita K, Kawamura T, Takahashi S, Tochiori S, Endou Y \& Sasaki T 2003 Expression of collagenase-3 (matrix metalloproteinase-13) in human gastric cancer. Gastric Cancer 6 30-38. (doi:10.1007/s101200300004)

Erwig LP \& Henson PM 2007 Clearance of apoptotic cells by phagocytes. Cell Death and Differentiation 15 243-250. (doi:10.1038/sj.cdd.440 2184)

Esslemont RJ \& Kossaibati MA 1996 Incidence of production diseases and other health problems in a group of dairy herds in England. Veterinary Record 139 486-490. (doi:10.1136/vr.139.20.486)

Farmer P, Girardot D, Lepage A, Regoli D \& Sirois P 2002 Inhibition of prostaglandin $\mathrm{G} / \mathrm{H}$ synthase unveils a potent effect of platelet activating factor on the permeability of bovine aortic endothelial cells to albumin. Inflammation 26 253-258. (doi:10.1023/A:1021477316559)
Foster SJ, Aked DM, Schroder JM \& Christophers E 1989 Acute inflammatory effects of a monocyte-derived neutrophil-activating peptide in rabbit skin. Immunology 67 181-183.

Freeman M, Ashkenas J, Rees DJ, Kingsley DM, Copeland NG, Jenkins NA \& Krieger M 1990 An ancient, highly conserved family of cysteine-rich protein domains revealed by cloning type I and type II murine macrophage scavenger receptors. PNAS 87 8810-8814.

Frijters R, Heupers B, van Beek P, Bouwhuis M, van Schaik R, de Vlieg J, Polman J \& Alkema W 2008 CoPub: a literature-based keyword enrichment tool for microarray data analysis. Nucleic Acids Research 36 W406-W410. (doi:10.1093/nar/gkn215)

Glickman JA \& Challis JR 1980 The changing response pattern of sheep fetal adrenal cells throughout the course of gestation. Endocrinology $\mathbf{1 0 6}$ 1371-1376. (doi:10.1210/endo-106-5-1371)

Goldenberg RL, Hauth JC \& Andrews WW 2000 Intrauterine infection and preterm delivery. New England Journal of Medicine 342 1500-1507. (doi:10.1056/NEJM200005183422007)

Goldman S \& Shalev E 2003 The role of the matrix metalloproteinases in human endometrial and ovarian cycles. European Journal of Obstetrics, Gynaecology, and Reproductive Biology 111 109-121. (doi:10.1016/S0301-2115(03)00341-5)

van Goor H, Melenhorst WB, Turner AJ \& Holgate ST 2009 Adamalysins in biology and disease. Journal of Pathology 219 277-286. (doi:10.1002/ path.2594)

Gootwine E 2004 Placental hormones and fetal-placental development. Animal Reproduction Science 82-83 551-566. (doi:10.1016/j.anireprosci.2004.04.008)

Gregory CD 2000 CD14-dependent clearance of apoptotic cells: relevance to the immune system. Current Opinion in Immunology 12 27-34. (doi:10.1016/S0952-7915(99)00047-3)

Gross TS, Williams WF \& Russek-Cohen E 2001 Cellular changes in the peripartum bovine fetal placenta related to placental separation. Placenta 12 27-35. (doi:10.1016/0143-4004(91)90507-C)

Haddad R, Romero R, Gould BR, Tromp G, Gotsch F, Edwin SS \& Zingg HH 2008 Angiogenesis gene expression in mouse uterus during the common pathway of parturition. American Journal of Obstetrics and Gynecology 198 539.e1-539.e8. (doi:10.1016/j.ajog.2007.11.021)

Haig D 2008 Placental growth hormone-related proteins and prolactin-related proteins. Placenta 29 (Suppl A) S36-S41. (doi:10.1016/ j.placenta.2007.09.010)

Hashizume K 2007 Analysis of uteroplacental-specific molecules and their functions during implantation and placentation in the bovine. Journal of Reproduction and Development 53 1-11. (doi:10.1262/jrd. 18123)

Herbach N, Goeke B, Schneider M, Hermanns W, Wolf E \& Wanke R 2005 Overexpression of a dominant negative GIP receptor in transgenic mice results in disturbed postnatal pancreatic islet and beta-cell development. Regulatory Peptides 125 103-117. (doi:10.1016/j.regpep.2004.08.021)

Heuwieser W, Grunert E \& Ehlert R 1985 Quantitative-determination of chemotactical activity in extirpated bovine placentomes, taking the discharge of the placenta into particular consideration. Berliner und Münchener Tierarztliche Wochenschrift 98 401-409.

Hsu SM, Raine L \& Fanger H 1981 Use of avidin-biotin-peroxidase complex $(A B C)$ in immunoperoxidase techniques - a comparison between $A B C$ and unlabeled antibody (PAP) procedures. Journal of Histochemistry \& Cytochemistry 29 577-580. (doi:10.1177/29.4.6166661)

Irizarry RA, Hobbs B, Collin F, Beazer-Barclay YD, Antonellis KJ, Scherf U \& Speed TP 2003 Exploration, normalization, and summaries of high density oligonucleotide array probe level data. Biostatistics 4 249-264. (doi:10.1093/biostatistics/4.2.249)

Joosten I \& Hensen EJ 1992 Retained placenta: an immunological approach. Animal Reproduction Science 28 451-461. (doi:10.1016/ 0378-4320(92)90132-W)

Keelan JA, Blumenstein M, Helliwell RJ, Sato TA, Marvin KW \& Mitchell MD 2003 Cytokines, prostaglandins and parturition - a review. Placenta 24 (Suppl A) S33-S46. (doi:10.1053/plac.2002.0948)

Kelly RW 1996 Inflammatory mediators and parturition. Reviews of Reproduction 1 89-96. (doi:10.1530/ror.0.0010089)

Kelly RW, Illingworth P, Baldie G, Leask R, Brouwer S \& Calder AA 1994 Progesterone control of interleukin-8 production in endometrium and chorio-decidual cells underlines the role of the neutrophil in menstruation and parturition. Human Reproduction 9 253-258. 
Livak KJ \& Schmittgen TD 2001 Analysis of relative gene expression data using real-time quantitative PCR and the $2(-$ Delta Delta $C(\mathrm{~T}))$ method. Methods 25 402-408. (doi:10.1006/meth.2001.1262)

Mayhew TM 2008 Taking tissue samples from the placenta: an illustration of principles and strategies. Placenta 29 1-14. (doi:10.1016/j.placenta. 2007.05.010)

McLaren J, Taylor DJ \& Bell SC 1999 Increased incidence of apoptosis in non-labour-affected cytotrophoblast cells in term fetal membranes overlying the cervix. Human Reproduction 14 2895-2900. (doi:10. 1093/humrep/14.11.2895)

McNaughton AP \& Murray RD 2009 Structure and function of the bovine fetomaternal unit in relation to the causes of retained fetal membranes. Veterinary Record 165 615-622. (doi:10.1136/vr.165.21. 615)

Mendelson CR 2009 Minireview: fetal-maternal hormonal signaling in pregnancy and labor. Molecular Endocrinology 23 947-954. (doi:10. 1210/me.2009-0016)

Miyoshi M, Sawamukai Y \& Iwanaga T 2002 Reduced phagocytotic activity of macrophages in the bovine retained placenta. Reproduction in Domestic Animals 37 53-56. (doi:10.1046/j.1439-0531.2002. 00332.x)

Moore RM, Mansour JM, Redline RW, Mercer BM \& Moore JJ 2006 The physiology of fetal membrane rupture: insight gained from the determination of physical properties. Placenta 27 1037-1051. (doi:10. 1016/j.placenta.2006.01.002)

Oksala N, Levula M, Airla N, Pelto-Huikko M, Ortiz RM, Jarvinen O, Salenius JP, Ozsait B, Komurcu-Bayrak E, Erginel-Unaltuna N et al. 2009 ADAM-9, ADAM-15, and ADAM-17 are upregulated in macrophages in advanced human atherosclerotic plaques in aorta and carotid and femoral arteries - tampere vascular study. Annals of Medicine 41 279-290. (doi:10.1080/07853890802649738)

Oliveira LJ \& Hansen PJ 2009 Phenotypic characterization of macrophages in the endometrium of the pregnant cow. American Journal of Reproductive Immunology 62 418-426. (doi:10.1111/j.1600-0897. 2009.00761.x)

Olson DM 2003 The role of prostaglandins in the initiation of parturition. Best Practice \& Research. Clinical Obstetrics \& Gynaecology 17 717-730. (doi:10.1016/S1521-6934(03)00069-5)

Olson DM, Mijovic JE \& Sadowsky DW 1995 Control of human parturition. Seminars in Perinatology 19 52-63. (doi:10.1016/S0146-0005(95) 80047-6)

Osmers R, Rath W, Adelmann-Grill BC, Fittkow C, Kuloczik M, Szeverenyi M, Tschesche H \& Kuhn W 1992 Origin of cervical collagenase during parturition. American Journal of Obstetrics and Gynecology 166 1455-1460.

Osmers RG, Blaser J, Kuhn W \& Tschesche H 1995 Interleukin-8 synthesis and the onset of labor. Obstetrics and Gynecology $\mathbf{8 6}$ 223-229. (doi:10.1016/0029-7844(95)93704-4)

Pap T, Shigeyama Y, Kuchen S, Fernihough JK, Simmen B, Gay RE, Billingham M \& Gay S 2000 Differential expression pattern of membrane-type matrix metalloproteinases in rheumatoid arthritis. Arthritis and Rheumatism 43 1226-1232. (doi:10.1002/1529-0131 (200006)43:6<1226::AID-ANR5 > 3.0.CO;2-4)

Prakash BS, Meyer HH, Schallenberger E \& van de Wiel DF 1987 Development of a sensitive enzymeimmunoassay (EIA) for progesterone determination in unextracted bovine plasma using the second antibody technique. Journal of Steroid Biochemistry 28 623-627. (doi:10.1016/ 0022-4731(87)90389-X)

Runic R, Lockwood CJ, LaChapelle L, Dipasquale B, Demopoulos RI, Kumar A \& Guller S 1998 Apoptosis and Fas expression in human fetal membranes. Journal of Clinical Endocrinology and Metabolism 83 660-666. (doi:10.1210/jc.83.2.660)

Rüsse I \& Sinowatz F 1991 Lehrbuch der Embryologie der Haustiere. Berlin: Paul Parey Verlag.

Schoon HA 1989 Lungen- und Plazentareifung beim Rind in der Endphase der Gravidität. Habilitation Thesis. School of Veterinary Medicine Hannover.

Schuler G, Wirth C, Teichmann U, Failing K, Leiser R, Thole H \& Hoffmann B 2002 Occurrence of estrogen receptor alpha in bovine placentomes throughout mid and late gestation and at parturition. Biology of Reproduction 66 976-982. (doi:10.1095/biolreprod66.4.976)
Sharpe KL, Eiler H, Cullen WC \& Hopkins FM 1989 Morphometric analysis of collagen in gestational and retained bovine placentomes. Theriogenology 32 485-491. (doi:10.1016/0093-691X(89)90015-0)

Sheldon IM 2004 The postpartum uterus. Veterinary Clinics of North America. Food Animal Practice 20 569-591. (doi:10.1016/j.cvfa.2004. 06.008)

Sheldon IM, Williams EJ, Miller AN, Nash DM \& Herath S 2008 Uterine diseases in cattle after parturition. Veterinary Journal 176 115-121. (doi:10.1016/j.tvjl.2007.12.031)

Sowter HM, Ratcliffe PJ, Watson P, Greenberg AH \& Harris AL 2001 HIF-1-dependent regulation of hypoxic induction of the cell death factors BNIP3 and NIX in human tumors. Cancer Research 61 6669-6673.

Spilsbury K, O'Mara MA, Wu WM, Rowe PB, Symonds G \& Takayama Y 1995 Isolation of a novel macrophage-specific gene by differential cDNA analysis. Blood 85 1620-1629.

Stallmach T, Hebisch G, Meier K, Dudenhausen JW \& Vogel M 2001 Rescue by birth: defective placental maturation and late fetal mortality. Obstetrics and Gynecology 97 505-509. (doi:10.1016/S0029-7844 (00)01208-4)

Steenport M, Khan KM, Du B, Barnhard SE, Dannenberg AJ \& Falcone DJ 2009 Matrix metalloproteinase (MMP)-1 and MMP-3 induce macrophage MMP-9: evidence for the role of TNF-alpha and cyclooxygenase-2. Journal of Immunology 183 8119-8127. (doi:10.4049/ jimmunol.0901925)

Stepan H, Purz S, Leo C, Hockel M \& Horn LC 2004 Localization and expression of the pro-apoptotic "cell death" factor BNIP3 in placentas from hypertensive pregnancies. Pathology, Research and Practice 200 329. (doi:10.1016/S0344-0338(04)80677-0)

Straszewski-Chavez SL, Abrahams VM, Funai EF \& Mor G 2004 X-linked inhibitor of apoptosis (XIAP) confers human trophoblast cell resistance to Fas-mediated apoptosis. Molecular Human Reproduction 10 33-41. (doi:10.1093/molehr/gah001)

Takagi M, Fujimoto S, Ohtani M, Miyamoto A, Wijagunawardane MP, Acosta TJ, Miyazawa K \& Sato K 2002 Bovine retained placenta: hormonal concentrations in fetal and maternal placenta. Placenta $\mathbf{2 3}$ 429-437. (doi:10.1053/plac.2002.0824)

Takagi M, Yamamoto D, Ohtani M \& Miyamoto A 2007 Quantitative analysis of messenger RNA expression of matrix metalloproteinases (MMP-2 and MMP-9), tissue inhibitor-2 of matrix metalloproteinases (TIMP-2), and steroidogenic enzymes in bovine placentomes during gestation and postpartum. Molecular Reproduction and Development 74 801-807. (doi:10.1002/mrd.20637)

Taverne MA \& Noakes DE 2009 Parturition and care of the parturient animal, including the newborn. In Veterinary Reproduction and Obstetrics, pp. 154-205. London: Saunders Elsevier.

Teesalu T, Masson R, Basset P, Blasi F \& Talarico D 1999 Expression of matrix metalloproteinases during murine chorioallantoic placenta maturation. Developmental Dynamics 214 248-258. (doi:10.1002/ (SICI)1097-0177(199903)214:3 < 248::AID-AJA8 > 3.0.CO;2-N)

Tsatas D, Baker MS \& Rice GE 1999 Differential expression of proteases in human gestational tissues before, during and after spontaneous-onset labour at term. Journal of Reproduction and Fertility 116 43-49. (doi:10. 1530/jrf.0.1160043)

Tusher VG, Tibshirani R \& Chu G 2001 Significance analysis of microarrays applied to the ionizing radiation response. PNAS $\mathbf{9 8} 5116-5121$. (doi:10.1073/pnas.091062498)

Ulug U, Goldman S, Ben-Shlomo I \& Shalev E 2001 Matrix metalloproteinase (MMP)-2 and MMP-9 and their inhibitor, TIMP-1, in human term decidua and fetal membranes: the effect of prostaglandin $\mathrm{F}$ (2alpha) and indomethacin. Molecular Human Reproduction 7 1187-1193. (doi:10. 1093/molehr/7.12.1187)

Vallon R, Muller R, Moosmayer D, Gerlach E \& Angel P 1997 The catalytic domain of activated collagenase I (MMP-1) is absolutely required for interaction with its specific inhibitor, tissue inhibitor of metalloproteinases-1 (TIMP-1). European Journal of Biochemistry 244 81-88. (doi:10. 1111/j.1432-1033.1997.00081.x)

Walter I \& Boos A 2001 Matrix metalloproteinases (MMP-2 and MMP-9) and tissue inhibitor-2 of matrix metalloproteinases (TIMP-2) in the placenta and interplacental uterine wall in normal cows and in cattle with retention of fetal membranes. Placenta 22 473-483. (doi:10.1053/ plac.2001.0633) 
Weinreb RN, Kashiwagi K, Kashiwagi F, Tsukahara S \& Lindsey JD 1997 Prostaglandins increase matrix metalloproteinase release from human ciliary smooth muscle cells. Investigative Ophthalmology \& Visual Science 38 2772-2780.

Whittle WL, Holloway AC, Lye SJ, Gibb W \& Challis JR 2000 Prostaglandin production at the onset of ovine parturition is regulated by both estrogenindependent and estrogen-dependent pathways. Endocrinology 141 3783-3791. (doi:10.1210/en.141.10.3783)

Williams WF, Margolis MJ, Manspeaker J, Douglass LW \& Davidson JP 1987 Peripartum changes in the bovine placenta related to fetal membrane retention. Theriogenology 28 213-223. (doi:10.1016/0093691X(87)90268-8)

Winkler M \& Rath W 1996 The role of cytokines in the induction of labor, cervical ripening and rupture of the fetal membranes. Zeitschrift für Geburtshilfe und Neonatologie 200 (Suppl 1) 1-12.

Woicke J, Schoon HA, Heuwieser W, Schulz LC \& Grunert E 1986 Morphological and functional aspects of placental maturing mechanisms in the cow. 1. Light microscopic findings. Zentralblatt Für Veterinärmedizin Reihe A 33 660-667.

Wood CE 1999 Control of parturition in ruminants. Journal of Reproduction and Fertility. Supplement 54 115-126.

Wooding FB, Morgan G \& Adam CL 1997 Structure and function in the ruminant synepitheliochorial placenta: central role of the trophoblast binucleate cell in deer. Microscopy Research and Technique 38 88-99. (doi:10.1002/(SICl)1097-0029(19970701/15)38:1/2<88:: AID-JEMT10 > 3.0.CO;2-A)

Wyatt SM, Kraus FT, Roh CR, Elchalal U, Nelson DM \& Sadovsky Y 2005 The correlation between sampling site and gene expression in the term human placenta. Placenta 26 372-379. (doi:10.1016/j.placenta.2004.07.003)
Yellon SM, Mackler AM \& Kirby MA 2003 The role of leukocyte traffic and activation in parturition. Journal of the Society for Gynecologic Investigation 10 323-338. (doi:10.1016/S1071-5576(03)00116-3)

Yoshida M, Sagawa N, Itoh H, Yura S, Takemura M, Wada Y, Sato T, Ito A \& Fujii S 2002 Prostaglandin F(2alpha), cytokines and cyclic mechanical stretch augment matrix metalloproteinase-1 secretion from cultured human uterine cervical fibroblast cells. Molecular Human Reproduction 8 681-687. (doi:10.1093/molehr/8.7.681)

Zachary I 1998 Vascular endothelial growth factor. International Journal of Biochemistry \& Cell Biology 30 1169-1174. (doi:10.1016/S1357-2725 (98)00082-X)

Zhao H, Bernardo MM, Osenkowski P, Sohail A, Pei D, Nagase $H$, Kashiwagi M, Soloway PD, DeClerck YA \& Fridman R 2004 Differential inhibition of membrane type 3 (MT3)-matrix metalloproteinase (MMP) and MT1-MMP by tissue inhibitor of metalloproteinase (TIMP)-2 and TIMP-3 regulates pro-MMP-2 activation. Journal of Biological Chemistry 279 8592-8601. (doi:10.1074/jbc.M308708200)

Zhao Y, Lyons CE Jr, Xiao A, Templeton DJ, Sang QA, Brew K \& Hussaini IM 2008 Urokinase directly activates matrix metalloproteinases-9: a potential role in glioblastoma invasion. Biochemical and Biophysical Research Communications 369 1215-1220. (doi:10.1016/j.bbrc.2008. 03.038)

Received 9 June 2011

First decision 4 July 2011

Revised manuscript received 18 October 2011

Accepted 26 October 2011 